\title{
Cdc-Like Kinases (CLKs): Biology, Chemical Probes, and Therapeutic Potential
}

\author{
Paula Martín Moyano ${ }^{1, \dagger}$, Václav Němec ${ }^{1,2, \dagger}$ and Kamil Paruch ${ }^{1,2, *}$ \\ 1 Department of Chemistry, Faculty of Science, Masaryk University, Kamenice 5, 62500 Brno, Czech Republic; \\ 242772@mail.muni.cz (P.M.M.); nemecvasek2@gmail.com (V.N.) \\ 2 International Clinical Research Center, Center for Biomolecular and Cellular Engineering, \\ St. Anne's University Hospital in Brno, 60200 Brno, Czech Republic \\ * Correspondence: paruch@chemi.muni.cz \\ + These authors contributed equally to this work.
}

Received: 31 August 2020; Accepted: 9 October 2020; Published: 13 October 2020

check for updates

\begin{abstract}
Protein kinases represent a very pharmacologically attractive class of targets; however, some members of the family still remain rather unexplored. The biology and therapeutic potential of cdc-like kinases (CLKs) have been explored mainly over the last decade and the first CLK inhibitor, compound SM08502, entered clinical trials only recently. This review summarizes the biological roles and therapeutic potential of CLKs and their heretofore published small-molecule inhibitors, with a focus on the compounds' potential to be utilized as quality chemical biology probes.
\end{abstract}

Keywords: CLK; cdc-like kinase; inhibitor; chemical biology; tool compound; chemical probe; T3; SGC-CLK-1; MU1210; SM08502

\section{Introduction}

Protein kinases play pivotal roles in nearly every aspect of cellular function [1]. Chemically, they transfer the $\gamma$-phosphate group from nucleoside triphosphate (typically ATP or GTP) to the hydroxyl group of serine, threonine, or tyrosine residues of the physiological substrate. Once the substrate is phosphorylated, it is released from the kinase and the remaining nucleoside diphosphate is recycled. The transfer of electrostatically charged phosphate group to an amino acid side chain of the target protein is often accompanied with conformational changes of the protein; thus, phosphorylation can act as a molecular "on-off" switch that strongly increases or decreases the enzymatic activity and/or the stability of the phosphorylated protein [2,3]. It has been estimated that about up to $30 \%$ of all human proteins can be phosphorylated by kinases [4,5].

Phosphorylation of proteins can lead to activation or deactivation of signal-transduction pathways that are important in various biological processes such as metabolism, transcription, cell cycle progression, cell movement, apoptosis, and differentiation. Over the past three decades, the protein kinase family has emerged as one of the most important classes of drug targets because mutations and dysregulations of protein kinases are frequently involved in the initiation and progression of cancers and other diseases [4,6-9].

Some kinases (e.g., BCR-ABL, BTK, AKT, VEGFR, etc.) have been established as attractive targets for pharmacological inhibition for a relatively long time $[10,11]$ while others, with the increasing knowledge of the cellular mechanisms, have come to the forefront only recently [11-14].

The kinase-driven cellular processes include also alternative and constitutive splicing, which are pivotal for gene expression $[15,16]$. Alternative splicing gives rise to higher complexity and diversity of transcriptome via the production of alternatively spliced mRNAs, which is consequently mirrored by the higher diversity of the proteome [16,17]. Aberrant splicing is responsible for the inaccurate 
translation of genetic information into the structure of proteins, which has often a negative impact on various cellular processes [18-21]. The splicing process is, to a large extent, regulated by protein kinases that phosphorylate splicing factors-central components of the spliceosome, for example, serine/arginine-rich proteins (SR proteins) —and less directly also by other kinases involved in cellular signaling pathways $[19,22]$.

SR proteins are splicing factors that interact simultaneously with RNA (via the RNA recognition motif RRM) and other proteins (via the RS domain containing arginine/serine residue repeats). They are employed in cellular processes such us constitutive and alternative pre-mRNA splicing, mRNA nuclear export, nonsense-mediated decay, and mRNA translation [23-26]. As summarized in recent reviews $[16,19,22,27]$, SR-protein phosphorylation can be executed by SR protein kinases (SRPKs), topoisomerase 1 (TOP1), protein kinase B (PKB/AKT), NIMA-related kinase2 (NEK2), PRP4 kinase (PRP4K), dual-specificity tyrosine phosphorylation-regulated kinase 1A (DYRK1A) [28,29], cAMP-dependent protein kinase (PKA) [30,31], and by the family of cdc-like kinases (CLKs), which are the subject of this review.

Other kinases involved in the regulation of splicing include MAPKs (acting via the RAS-RAF-MEK-ERK signaling cascade), tyrosine kinases (BRK, FYN, SRC, c-ABL), Fas-activated serine/threonine kinase (FAST) [32], and possibly also AURKA [33]. Those kinases can influence the splicing via phosphorylation of splicing factors such as SAM68 (e.g., RAS-RAF-MEK-ERK cascade) [34] or more indirectly via phosphorylation of their upstream effectors.

Despite significant scientific progress in the area over the past decade, the biology of CLKs has not been completely elucidated and, particularly, the roles of individual CLK isoforms remain largely unexplored. These questions could be, at least partially, addressed by the utilization of the recently discovered highly selective tool compounds (quality probes) that are summarized in this review.

\section{Classification and Structure of CLKs}

Protein kinases form a large family of more than 500 proteins with common characteristics that can be clustered into phylogenetic groups (Figure 1) [35].

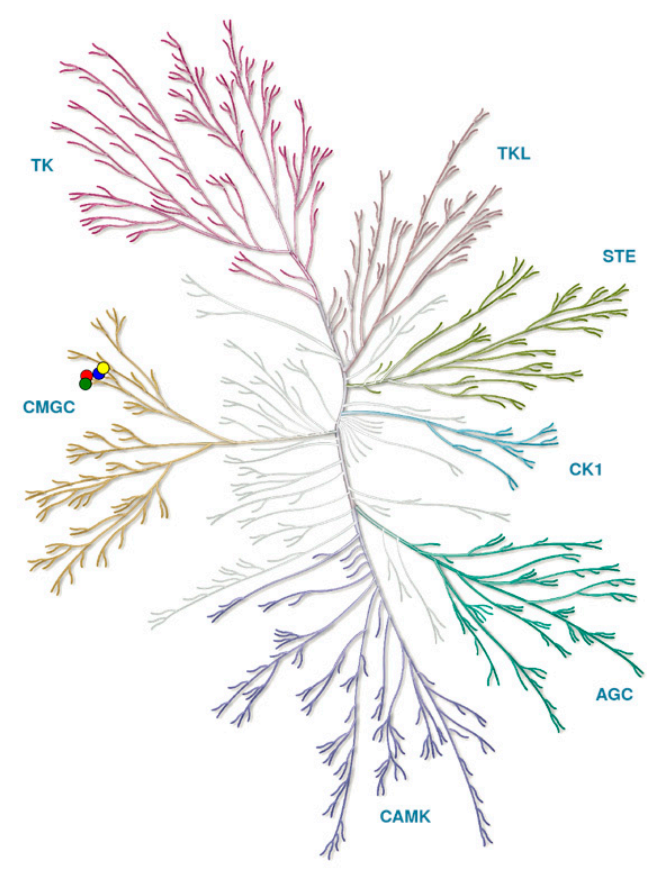

Figure 1. Kinome tree with CLKs marked by circles: CLK1 (blue), CLK2 (red), CLK3 (green), CLK4 (yellow). Source: KinMap software. Illustration reproduced courtesy of Cell Signaling Technology, Inc. (www.cellsignal.com). 
The group CMGC (named after initials of some key members) includes several subgroups: Cyclic Dependent Kinases (CDKs), Mitogen-Activated Protein Kinases (MAPKs), Glycogen Synthase Kinases (GSKs), and CLKs, first reported in 1991 [36,37].

Overall, CMGC is a large and well-conserved group of kinases that have pivotal roles in cell cycle regulation and intracellular signal transduction.

The CLK family consists of CLK1, CLK2, CLK3, and CLK4, which are briefly summarized in Table 1, with highlighted differences in the ATP-binding region. The full amino acid sequences are given in Figure 2.

Table 1. Human CLKs: amino acid residues count, mass in $\mathrm{kDa}$, and amino acids present in the ATP phosphates' binding region (the residues specific for individual isoform are in bold) [38].

\begin{tabular}{|c|c|c|c|}
\hline $\begin{array}{l}\text { CLK Form } \\
\text { (Uniprot Ref.) }\end{array}$ & $\begin{array}{l}\text { Amino Acid } \\
\text { Residues }\end{array}$ & kDa & Amino Acids in the ATP Phosphates' Binding Region \\
\hline $\begin{array}{c}\text { CLK1 } \\
(\mathrm{P} 49759)\end{array}$ & 484 & 57 & $\begin{array}{c}\text { 167-175 } \\
\text { (LGEGAFGKV) }\end{array}$ \\
\hline $\begin{array}{c}\text { CLK2 } \\
(\mathrm{P} 49760)\end{array}$ & 499 & 60 & $\begin{array}{c}\text { 169-177 } \\
\text { (LGEGTFGRV) }\end{array}$ \\
\hline $\begin{array}{c}\text { CLK3 } \\
(\mathrm{P} 49761)\end{array}$ & 638 & 73 & $\begin{array}{c}\text { 310-318 } \\
\text { (LGEGTFGKV) }\end{array}$ \\
\hline $\begin{array}{c}\text { CLK4 } \\
\text { (Q9HAZ1) }\end{array}$ & 481 & 57 & $\begin{array}{c}165-173 \\
\text { (LGEGAFGKV) }\end{array}$ \\
\hline
\end{tabular}

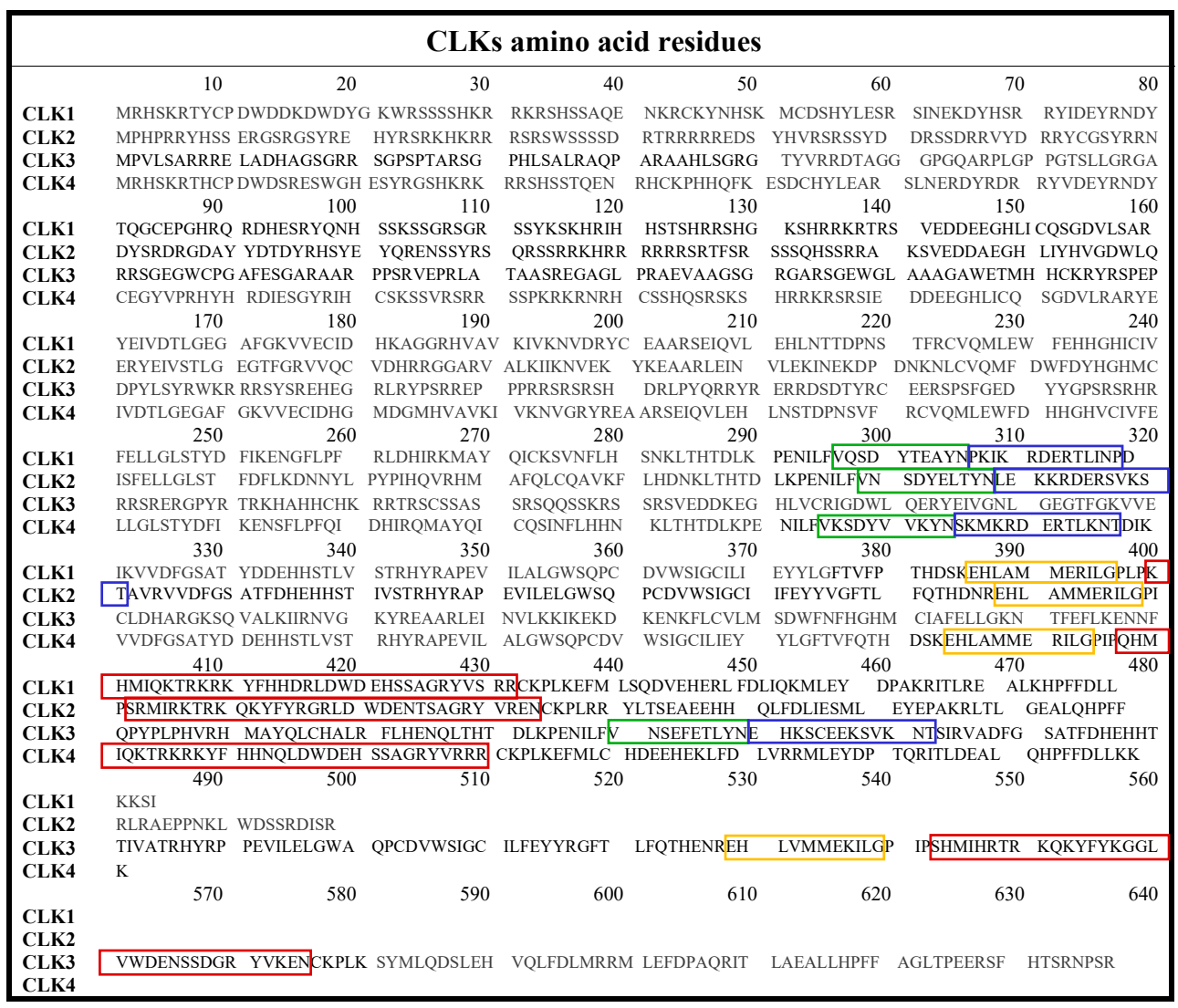

Figure 2. Amino acid sequences of CLK1-4 with color-coded insertions: MAPK-like insertion (red), LAMMER motif (yellow), $\beta$-hairpin: $\beta-9$ (green), and $\beta-10$ (blue) [38]. 
The structures of CLKs are quite typical and consist of the N- and C-lobes connected by the "hinge" region of the protein backbone including the ATP binding site, which is conserved as in other kinases [39-41]. As for other kinases, the binding of the purine part of ATP is very likely provided by hydrogen bonding to the $\mathrm{NH}$ (donor) and $\mathrm{CO}$ (acceptor) motifs in the protein backbone (Figure 3). Additional CO is available as an acceptor site [42].

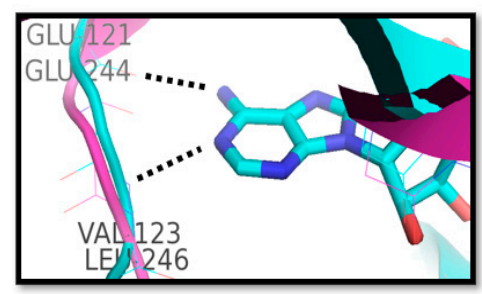

hinge region

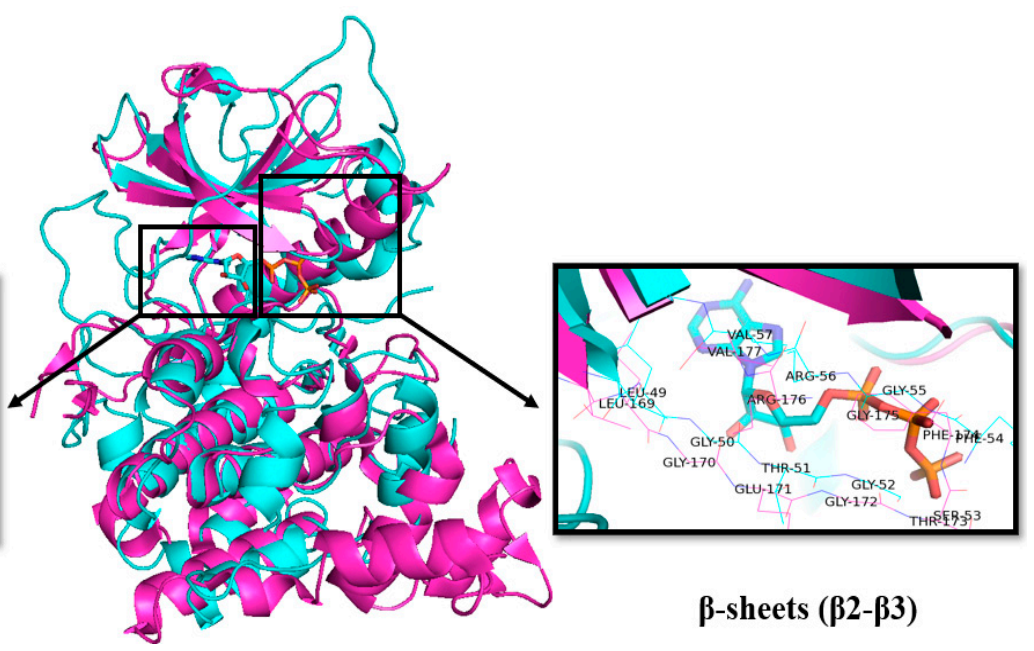

Figure 3. Overlap of the crystal structures of CLK2 (pink, PDB: 3NR9) [43] and PKA with bound ATP (blue, PDB: 1ATP) [44]. Key amino acid residues in the ATP binding region are highlighted by boxes.

The Glu residue in the back region of the ATP-binding site forms an ion pair with Lys, which facilitates the transfer of the $\gamma$-phosphate from ATP [40].

The structures of CLKs contain catalytic domains with $\beta$-strands and $\alpha$-helixes distributed between the $\mathrm{N}$ - and C-regions. The $\mathrm{N}$-lobe contains three $\beta$-strands followed by $\alpha$-helix and additional two $\beta$-strands (Figure 3) $[39,45]$.

The tertiary structures of all CLKs are quite similar (Figure 4), nevertheless the structure of CLK3 contains some additional motifs (Figure 2), as described below [39,45,46].

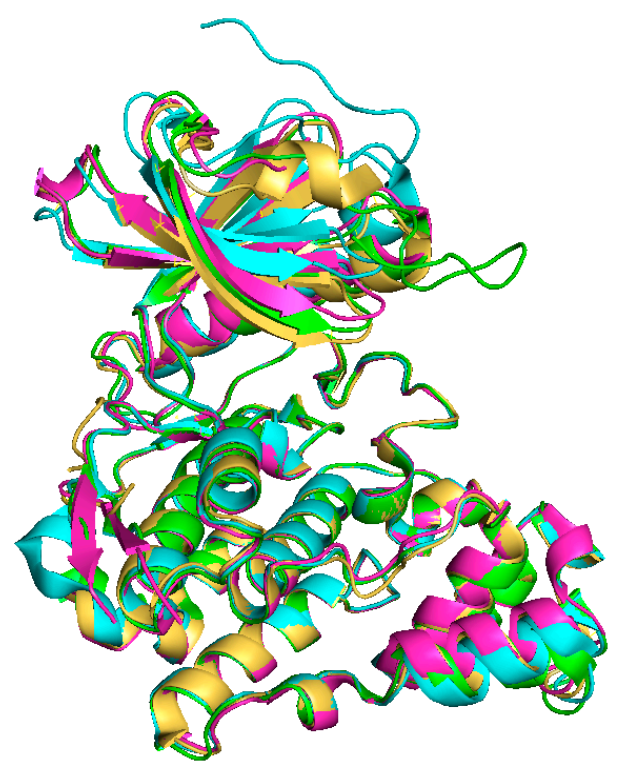

Figure 4. Overlay of X-ray crystal structures: CLK1 (yellow, ligand:12h, PDB: 6I5H) [47], CLK2 (green, PDB: 3NR9) [43], CLK3 (blue, PDB: 6YTW [48], CLK4 (pink, ligand: CX4945, PDB: 6FYV) [45,49]. 
CLK3 contains a small insert between stands $\beta 6$ and $\beta 9$ in the kinase core that interacts with a hydrophobic pocket near the hinge region that connects the $\mathrm{N}$ - and C-lobes [50]. The C-lobe of CLK3 is formed by three conserved regions: the LAMMER motif, mitogen-activated insertion, the MAPK-like insertion containing an $\alpha 8$ (residues 419-427), and $\beta$-hairpin insertion (Figures 2 and 5) [45,50].

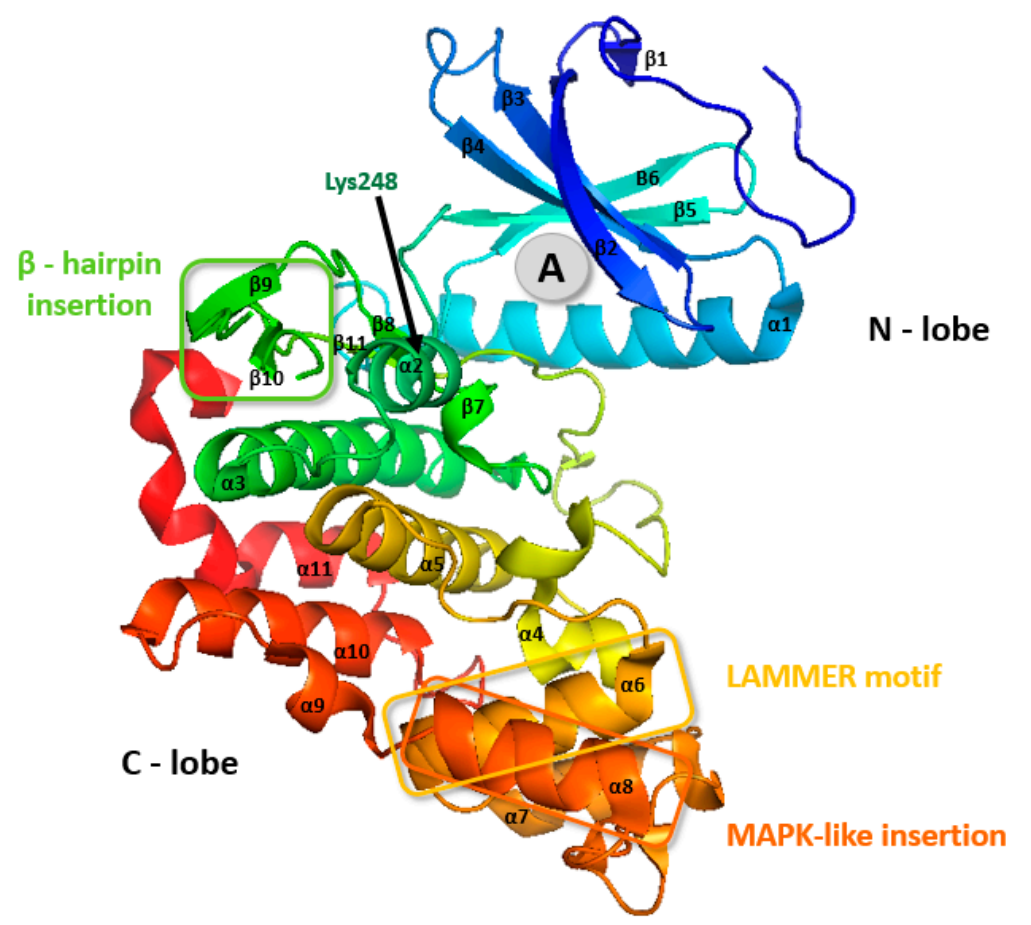

Figure 5. CLK3 crystal structure. The grey circle (A) represents the most common binding pocket for small-molecule inhibitors. PDB: 2EU9 [51].

There are two "extra" elements that are not present in CLK1: the first one consists of inserted residues in the hairpin (residues 136-145) folding above the N-terminal domain, the second one is a supplementary helical segment at the C terminus (residues 476-481) [39].

Also, CLK3 possesses one Lys248 residue in the entrance of the active site pocket (Figure 5), which modifies the electrostatic surface charge distribution therein-this might be unfavorable for the entry of some CLK inhibitors $[45,46]$.

Given the structural features of CLK3 described above, it is perhaps not surprising that various small-molecule inhibitors frequently exhibit different affinities toward CLK3 compared to the other CLKs (see the chapter "Small-molecule CLK inhibitors" below).

\section{Biology of CLKs}

CLKs are evolutionary conserved dual-specificity kinases that are able to phosphorylate serine, threonine, and tyrosine residues [36,52]. CLKs catalyze the phosphorylation of SR proteins, serine, and arginine-rich splicing factors 1-12 (SRSF1-12), which regulate the spliceosome molecular machinery [53-55]. SR proteins seem to have very distinct functions based on their phosphorylation state [56], as reported, for example, for SRSF10 (SRp38) [57,58]. Upon hyper-phosphorylation, SR proteins bind to pre-mRNA and help to stabilize interactions between spliceosome components, which results in spliceosome assembly [27,59-61]. Conversely, de-phosphorylation of SR proteins by phosphatases is required in the second step for the pre-mRNA splicing [59-61] and subsequently for the export of spliced mRNA to the cytoplasm [26,62]. Via this mechanism, CLKs regulate pre-mRNA splicing and consequently also the translation of genetic information into protein structure $[63,64]$.

All CLK isoforms have been found in most tissues and cell types (e.g., prostate, leukocytes, testes, muscle, brain, liver, lung, kidney, thyroid), but their expression levels differ in some tissues. 
For instance, CLK1 expression level in the testes was significantly lower than those of CLK2-4 [53,65-67]. All CLK isoforms are mostly localized in the nucleus; however, in the testes, CLK3 was found to be localized mostly in stress granules in the cytoplasm $[16,52,68]$. In contrast, SRPKs were found mostly in the cytoplasm and only a minor fraction was observed in the nucleus [69,70].

Interestingly, CLK1/4 activity is highly responsive to physiological temperature changes, which is caused by reversible temperature-dependent rearrangements in the kinase activation segment, reflected in temperature-dependent SR protein phosphorylation, splicing, and gene expression [71]. Specifically, it has been shown that lower body temperature causes activation of CLK1/4, which leads to increased SR protein phosphorylation.

The mRNAs of all CLK isoforms are alternatively spliced. The spliced variants form heterodimers with full-length CLKs, showing that alternative splicing mediated by CLKs is auto-regulated [69]. CLKs are mostly localized in the nucleus, but their localization has been described also in the cytoplasm (e.g., in stress granules) [16,52,68], although less abundantly than SRPKs [69,70].

CLKs are capable of auto-phosphorylation on Tyr residues, while their substrates are phosphorylated on Ser/Thr residues [53]. In contrast to SRPKs, which phosphorylate only Arg-Ser dipeptides, CLKs can phosphorylate both Arg-Ser and Ser-Pro dipeptides-common motifs in all SR proteins [50]. It has been reported that CLK1/2/4 isoforms phosphorylate Aurora B-S331 in the midbody during late cytokinesis, which leads to Aurora $B$ activation and consequently to the regulation of abscission checkpoint [72].

Via regulation of splicing, CLKs (indirectly) affect a variety of biological processes [73-75]. For instance, it has been described that CLKs modulate alternative splicing of key Wnt-related genes and consequently the Wnt signaling pathway [76]. CLKs regulate also the splicing of the TAU protein which plays an essential role in the stabilization of microtubules and thereby impacts processes such as cell division and neuronal activity [77-79].

The CLK family consists of four isoforms (CLK1-4); however, the knowledge about their individual biological roles is still rather limited.

\subsection{CLK1}

CLK1 (alternatively referred to as STY) represents one of the first kinases with dual specificity described in the literature and also the most explored CLK isoform up today [36]. CLK1 has been found to regulate alternative splicing of its own gene $c l k 1$ via exon 4 skipping and intron 4 retention [80]. Thus, CLK1 forms an auto-regulatory loop where the catalytically active CLK1 triggers the expression of truncated isoforms CLK1 ${ }^{\mathrm{T} 1}$ and $C L K^{\mathrm{T} 2}$ [80]. In contrast, extrinsic stress factors or CLK1 inhibition promote the expression of full-length CLK1 [80]. CLK1 possesses a diffuse nuclear localization sequence (NLS) in the $\mathrm{N}$ terminus that is responsible for the formation of oligomeric CLK1, which is likely unable to pass through nuclear pores [81]. On the other hand, NLS strongly interacts with its substrate SRSF1 (SR protein), which is very likely important for the nuclear import of CLK1 via a "piggyback" mechanism, where CLK1 is transported inside the nucleus together with the TRN-SR2/SRSF1 complex (Figure 6). This mechanism has been supported by various experiments, for example, disruption of SRSF1 protein transport by TRN-SR2 knockdown or mutation of the SRSF1 NLS impaired CLK1 nuclear localization [68]. 


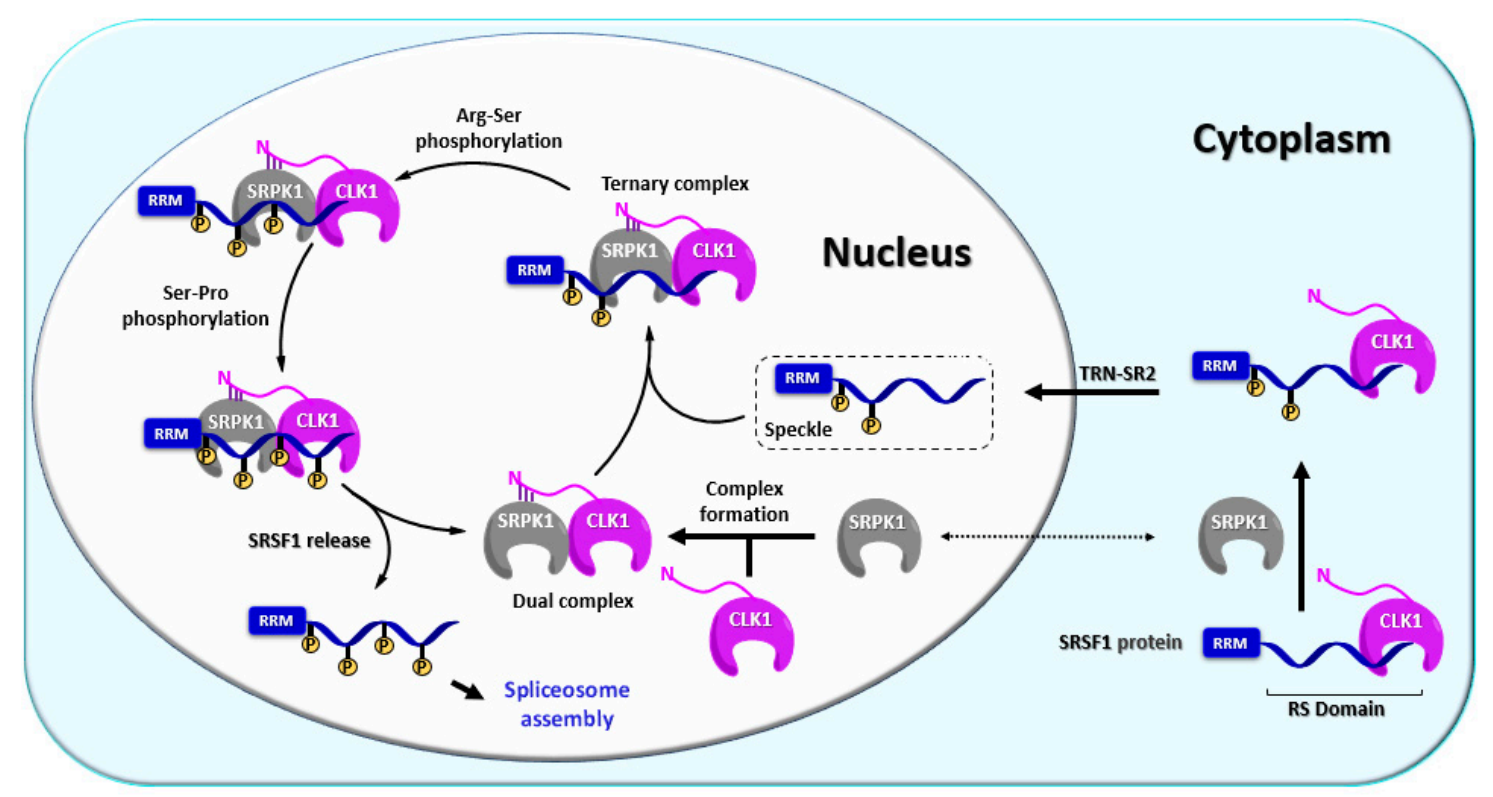

Figure 6. Schematic representation of the phosphorylation mechanism involving CLK1 [39,49,55,68,82-85].

Not only nuclear import but also nuclear function has been described most thoroughly for the CLK1 isoform, namely its regulation mechanism of the SR protein SRSF1 $[55,68,85,86]$. In this process, CLK1 and SRPK1 work co-operatively as a complex [55]. The complex containing CLK1 in active form first recruits hypo-phosphorylated SRSF1 from nuclear speckles (also termed interchromatin granule clusters), which act as a pool of SR proteins in the nucleus, whereby a ternary complex CLK1-SRPK1-SRSF1 is formed (Figure 6). The ternary complex executes full phosphorylation of SRSF1 and subsequently releases it (Figure 6) $[55,84,85]$. Alternatively, CLK1 itself can form a complex with SRSF1 and catalyze full phosphorylation first. Subsequently, SRPK1 can engage to create the ternary complex CLK1-SRPK1-SRSF1 [85]. The interaction between CLK1 N-terminus and SRPK1 kinase domain holds the complex CLK1-SRPK1 together but also facilitates the release of hyper-phosphorylated SRSF1 from the ternary complex, which is a prerequisite for the assembly of spliceosome [55]. It has been also suggested that the interaction between CLK1 and SRPK1 anchors the SRPK1 in the nucleus, thereby increasing SRPK1 concentration in the nucleoplasm [55]. In addition, CLK1 phosphorylates the splicing factor SPF45 (non-SR protein) on eight serine residues, regulating cell migration and invasion (SPF45 overexpression promotes both processes) [87].

CLK1 can be phosphorylated by AKT2, which promotes CLK1-mediated SR protein phosphorylation [88]. In addition, CLK1 also activates KKT2 via phosphorylation at the S508 residue, which is crucial for kinetochore assembly [89], documenting that the CLK1 is a component of a wider signaling network.

In addition, CLK1 can regulate autophagy-CLK1 inhibition or knockout induces autophagy via activation of the mTOR/PI3K pathway $[90,91]$.

These recent findings suggest it may be desirable to evaluate the effect of CLK inhibitors on splicing in the context of the SRPK1-CLK1 complex, rather than using the isolated CLK1 kinase [85].

\subsection{CLK2}

Specifically for CLK2, it has been found that it can be stabilized by AKT in response to feeding and acts as a suppressor of the peroxisome proliferator-activated receptor $\gamma$ coactivator (PGC-1 $\alpha$ ), thus modulating fatty acid oxidation and ketogenesis [92]. In addition, it has been reported that CLK2 phosphorylates the protein phosphatase 2A (PP2A), which leads to assembly of the heterotrimeric PP2A holoenzyme, subsequent AKT dephosphorylation, and attenuation of AKT activity [93]. 
CLK2 phosphorylation by activated AKT is an important regulatory mechanism promoting cell survival following ionizing radiation [94].

Besides the role of CLK2 in SR protein phosphorylation and splicing regulation, it has been documented that CLK2 and CLK1 also phosphorylate the protein-tyrosine phosphatase PTP-1B, whereby increasing its activity [95].

Recent findings show that CLK2 hyper-phosphorylates Prostate-Associated Gene 4 (PAGE) at multiple Ser- and Tyr-residues. Interestingly, it has been documented that HIPK1-phosphorylated PAGE4 potentiates c-JUN whereas CLK2-phosphorylated PAGE4 diminishes c-JUN activity [96].

\subsection{CLK3}

High levels of CLK3 were detected in mature spermatozoa in mouse testes. Interestingly, CLK3 in these cells is mainly located in the cytoplasm [97].

\subsection{CLK4}

CLK4 and CLK1 are almost identical in amino acid sequence. CLK1/4 proteins supplied through stress-induced splicing of the intron-retaining pre-mRNAs have been found to be essential for the rapid recovery of the phosphorylation state of SR proteins and contribute to the restart of splicing reactions after stress removal. They may thus serve as a guardian maintaining the phosphorylation state of SR proteins to improve the survival of cells exposed to stress [98].

\section{Effects of Altered CLK Expression}

On the molecular level, an increased level of CLKs has been found to lead to the following.

Overexpression of active CLKs causes the redistribution of SR proteins within the nucleus and dissolution of speckles [54,56,99], dispersion of eIF4E nuclear speckles [100], complete redistribution of interchromatin granule clusters [101], and specific targeting of SRp55 for degradation by proteasome [102].

The overexpression of CLK1 also affects splicing site selection of pre-mRNA of both its own transcript and adenovirus E1A transcripts in vivo [103]. CLK1 regulates expression of the alternative splicing factor 45 (SPF45), which is frequently overexpressed in cancer. Expression of CLK1 enhances SPF45-induced exon 6 exclusion from Fas mRNA, whereas CLK1 inhibition reduces it [87]. In human stem cells, overexpression of CLK2 leads to the dispersal of speckles and a significant drop in the number of genes in shared neighborhoods [104]. On the morphological and phenotypical levels, altered expression of CLK has been found to elicit different changes, summarized below.

Expression of CLKs in PC12 cells mimic nerve growth factor (NGF)-dependent events, including morphological differentiation and elaboration of neurites up-regulated during HMBA-induced erythroleukemia cell differentiation [105]. Rather conversely, a reduction in transcript levels for CLK1 (and other genes encoding proteins involved in neurite outgrowth, namely NGF, M6a, and GNAQ) was observed in chronically stressed mice [106]. In Xenopus embryos, overexpression of CLK2 induces expression of both anterior and posterior neural marker genes, thereby promoting early neural development [107]. Overexpression of CLK2 significantly increases the growth of HeLa cells and inhibits radiation-induced cell death [94]. CLK2 also acts as an oncogene in breast cancer-it is amplified and overexpressed in a significant fraction of breast tumors and its downregulation inhibits breast cancer growth in cell culture as well as in xenograft models [108]. Recently, CLK3 was found to be markedly upregulated in hepatocellular carcinoma tissues and its expression levels were closely associated with TNM stages and prognosis [109].

Overexpression of CLK2 in the mediobasal thalamus in mice on a high-fat diet can partially reverse the obese phenotype [110]. CLK2 regulates CREB via the attenuation of CREB inhibitory dephosphorylation by PP2Am, which affects diet-induced thermogenesis in brown adipose tissue via increased CREB-dependent expression of UCP1 [93]. There are indications that BAT CLK2 increases 
diet-mediated energy expenditure and protects against obesity [93]. Moreover, it has been shown that CLK2 is an insulin-regulated suppressor of hepatic gluconeogenesis [111].

\section{CLKs as Therapeutic Targets}

Compromised accuracy of alternative splicing can have a profound impact on human pathogenesis, in particular on tumor development and progression [112]. Recent reports described recurrent change-of-function mutations in splicing factors in a variety of cancers and suggested that abnormal splicing can trigger tumor growth [113-115]. As briefly illustrated in the previous chapter and described in greater detail here, there has been increasing experimental evidence that abnormal function and levels of CLKs are present in different cancers.

Cancer cells have general as well as cancer type-specific and subtype-specific alterations in the splicing process that can have prognostic value and contribute to cancer progression. These splicing alterations are often linked to the occurrence of cancer driver mutations in genes encoding either core components or regulators of the splicing machinery, which can make the cells particularly vulnerable to the pharmacological inhibition of splicing $[116,117]$. More specifically, there has been emerging evidence that splicing kinases are dysregulated in cancer and play important roles in both tumorigenesis as well as therapeutic response to radiation and chemotherapy [16].

A recent report demonstrated that MYC activation, which altered pre-mRNA splicing without the transcriptional regulation of CLKs, can render cancer cells vulnerable to CLK inhibitors with resulting synergistic cell death [118]. The potential therapeutic benefit of CLK inhibition was also demonstrated in vivo in an allograft model of spontaneous, MYC-driven breast cancer [118].

Numerous investigations of the cancer-related biology of CLKs have been supported by the use of small-molecule inhibitors (described in the following chapter) with varying degrees of selectivity. Of those, the inhibitor SM08502 recently entered clinical trials for the treatment of advanced solid tumors [76], and the compound CX-4945/silmitasertib (which inhibits CLK2 as well as CK2) [119] for the treatment of cholangiocarcinoma, medulloblastoma, basal cell carcinoma, and multiple myeloma [120]. CX-4945 could be also applicable in the treatment of glioblastoma where CLK2 modulates phosphorylation of Forkhead box O3a (FOXO3a)/p27 and, consequently, cell cycle and survival of tumor cells [121].

As exemplified below, CLKs could be attractive targets in other therapeutic areas beyond oncology. Despite their high homology, overexpression of CLK1 vs. CLK2 was found to have opposite effects on the replication of the HIV-1 virus, while changing the levels of CLK3 and CLK4 had no significant effect [122].

As described previously, the CLK-mediated phosphorylation process is involved in RNA splicing; however, aberrant splicing involving the microtubule-associated protein tau is associated with neurodegenerative diseases such as frontotemporal dementia and Parkinson's disease and other tauopathies $[78,123,124]$. Recent reports indicate that CLKs (and other kinases) can be involved in the molecular mechanism of Alzheimer's disease and [123,125,126] the CLK/DYRK inhibitor Leucettine 41 can activate the autophagic mTOR/PI3K pathway, which may represent a therapeutic option [91].

Pharmacological inhibition of CLK1 has been investigated pre-clinically (in mice) for the treatment of Duchenne muscular dystrophy-it resulted in enhanced mutated exon 31 skipping, which led to the production of functional exon 31 skipped dystrophin in cells derived from Duchenne muscular dystrophy patients [127].

CLK1 inhibition and CLK1 knockout effect also splicing of the viral RNA transcript. Specifically, it has been shown that CLK1 knockdown or inhibition reduced influenza A/WSN/33 virus replication in A549 cells [128]. Moreover, CLK1-/- mice infected with influenza A/England/195/2009 (H1N1pdm09) virus had lower levels of virus replication in comparison to wild-type mice, and CLK1 inhibition had a similar effect [128].

CLK2 is also considered as an insulin-regulated suppressor of hepatic gluconeogenesis, contributing to hyperglycemia in diabetes. The mechanism is principally based on direct 
phosphorylation of the SR domain of the transcriptional coactivator (PGC-1 $\alpha$ ) by CLK2. This phosphorylation process causes repression of gene expression in the gluconeogenesis, resulting in hypoglycemia [111]. Along this line, it has been suggested that the levels of insulin could be regulated by CLK2 inhibition $[88,111]$.

In neurology, inhibition of CLK2 was reported to restore normal sociability of Shank3-deficient mice (likely via activation of AKT activation) and thus could be therapeutically relevant for the treatment of the autistic spectra disorder Phelan-McDermid syndrome (PMDS) [129].

Finally, it has been reported that inhibition of CLK3 in Plasmodium falciparum (PfCLK3) represents a promising approach for the treatment of malaria via preventing the splicing of essential parasite genes. It has been demonstrated that CLK3 inhibition can kill multiple species of malaria parasites at the blood stage and at the liver-stage and block transmission of the parasite to mosquitoes $[130,131]$. Another indication where CLK inhibition could be therapeutically relevant is Legionellosis, where CLK inhibition (by TG003) was demonstrated to reduce Legionella growth within mouse macrophages [132].

\section{Small-Molecule CLK Inhibitors}

Over the last two decades, structurally diverse CLK inhibitors have been described in the literature, with the majority of them being published in recent years. This chapter provides a chronological summary of individual compounds and/or selected representatives of individual structural series, with the focus on substances that have been most thoroughly profiled and could thus serve as chemical probes for chemical biology studies (Table 2). For better comparison, Table 2 also contains data for structurally similar DYRKs and HIPKs, since achieving selectivity against those two sub-families is not trivial and represents a significant challenge in the development of selective CLK inhibitors. Additional typical off-targets of many CLK inhibitors are PIM and/or CK1 kinases.

Of note, most of the reported CLK inhibitors interact relatively weakly with CLK3-only 4 out of 24 compounds exhibit $\mathrm{IC}_{50} / \mathrm{K}_{\mathrm{d}}$ values towards CLK3 $<100 \mathrm{nM}$. Table 2 contains the published values obtained in primary biochemical assays; however, for their direct comparison it is important to keep in mind that these data were often obtained from various sources/assays or from the same (similar) assay but under unequal conditions (e.g., using different concentrations of ATP). On the other hand, some studies report a direct comparison of several (usually two or three) inhibitors from different classes/publications, profiling them in the same assay [76,133-136].

An additional brief summary is given for each of the inhibitors, with the main focus on their selectivity and (therefore) potential to be used as quality CLK chemical probes in chemical biology. It is likely that in the near future, highly selective tool compounds will help further unravel the complexity of CLK biology and validate the therapeutic potential of CLK inhibition. Of the listed CLK inhibitors, we highlight those that (in our opinion) fulfill the criteria for a quality probe. However, it is highly recommended to confirm the context of the obtained biological data in original reports prior to use and (whenever possible) use at least two chemically different quality chemical biology probes to minimize the risk of compound-specific off-target effects.

Some of the compounds exhibiting sufficient activity in the cell and in vivo have been pre-clinically profiled as anti-tumor agents $[76,135,137]$. Of note, the therapeutic potential of CLK inhibitors might be enhanced by simultaneous inhibition of additional targets [136,137]. 
Table 2. In vitro activities of known CLK inhibitors, including their typical off-targets. The $\mathrm{IC}_{50}$ values (in nM) are given as numbers, $\mathrm{Kd}$ values (in nM) are specified. In cases where $\mathrm{IC}_{50} / \mathrm{K}_{\mathrm{d}}$ is not available, the compound's potency is expressed as a percentage of the enzyme's residual activity at the concentration of the inhibitor specified in brackets. CLK probes recommended by SGC are highlighted in green. ND: no data found.

\begin{tabular}{|c|c|c|c|c|c|c|c|c|c|c|c|c|}
\hline \multirow[b]{2}{*}{ Compound } & \multicolumn{4}{|c|}{ CLKs } & \multicolumn{6}{|c|}{ Structurally Similar Kinases } & \multirow[t]{2}{*}{ Other Significant Targets } & \multirow[t]{2}{*}{ Kinases Screened } \\
\hline & CLK1 & CLK2 & CLK3 & CLK4 & DYRK1A & DYRK1B & DYRK2 & HIPK1 & HIPK2 & HIPK3 & & \\
\hline TG003 [64,134,138] & $\begin{array}{c}19 \\
\left(K_{d}\right)\end{array}$ & $\begin{array}{c}95 \\
\left(K_{d}\right)\end{array}$ & inactive & $\begin{array}{c}30 \\
\left(\mathrm{~K}_{\mathrm{d}}\right)\end{array}$ & $\begin{array}{c}12 \\
\left(\mathrm{~K}_{\mathrm{d}}\right)\end{array}$ & $\begin{array}{c}130 \\
\left(K_{d}\right)\end{array}$ & ND & ND & ND & ND & $\begin{array}{c}\text { CK1 } 1=150 \\
\text { CK1 } 1 \varepsilon=300 \\
\text { CK1 } 2=270 \\
\text { CK1 } 33=290 \\
\text { PIM1 } 1=130 \\
\text { PIM3 }=280 \\
\text { YSK } 4=290 \\
\left(K_{d}\right)\end{array}$ & $\sim 402$ kinases \\
\hline ML106 [134,138] & $\begin{array}{c}37 \\
\left(K_{d}\right)\end{array}$ & $\begin{array}{c}680 \\
\left(K_{d}\right)\end{array}$ & $\begin{array}{l}470 \\
\left(\mathrm{~K}_{\mathrm{d}}\right)\end{array}$ & $\begin{array}{c}50 \\
\left(K_{d}\right)\end{array}$ & $\begin{array}{c}27 \\
\left(K_{d}\right)\end{array}$ & $\begin{array}{l}430 \\
\left(K_{d}\right)\end{array}$ & ND & ND & ND & ND & $\mathrm{EGFR}=230\left(\mathrm{~K}_{\mathrm{d}}\right)$ & 402 kinases \\
\hline ML167 [138] & 1522 & 1648 & inactive & 136 & inactive & 4420 & ND & ND & ND & ND & Not published & 442 kinases \\
\hline $\begin{array}{c}\text { CX-4945 } \\
{[133,139,140]}\end{array}$ & 3.3 & 2.9 & 67 & 23 & 14 & ND & $\begin{array}{c}5 \% \\
(0.5 \mu \mathrm{M})\end{array}$ & $\begin{array}{c}11 \% \\
(0.5 \mu \mathrm{M})\end{array}$ & $\begin{array}{c}15 \% \\
(0.5 \mu \mathrm{M})\end{array}$ & $\begin{array}{c}7 \% \\
(0.5 \mu \mathrm{M})\end{array}$ & $\begin{array}{c}\text { CK2 } \alpha=1.5 \\
\text { PIM1 }=216 \\
\text { TBK1 } \\
\text { DAPK2 } \\
\text { ZIPK } \\
\text { FLT1 }\end{array}$ & $\sim 235$ kinases \\
\hline KH-CB19 [141] & 20 & ND & 530 & ND & 55 & ND & ND & ND & ND & ND & $\begin{array}{l}\text { PIM1/3 } \\
\text { SGK085 }\end{array}$ & $\begin{array}{l}106 \text { kinases } \\
\text { (thermal shift } \\
\text { assay) }\end{array}$ \\
\hline $\begin{array}{c}\text { Leucettine L L } \\
\text { [142] }\end{array}$ & 71 & 720 & inactive & 64 & 60 & 44 & 73 & $\begin{array}{c}1 \% \\
(10 \mu \mathrm{M})\end{array}$ & $\begin{array}{c}11 \% \\
(10 \mu \mathrm{M})\end{array}$ & $\begin{array}{c}4 \% \\
(10 \mu \mathrm{M})\end{array}$ & $\begin{array}{c}\text { GSK3 } \alpha=210 \\
\text { PIM1 } \\
\text { IRAK1 } \\
\text { TAOK1 }\end{array}$ & 402 kinases \\
\hline ML315 [143] & 68 & 231 & inactive & 68 & 282 & 1156 & ND & ND & ND & ND & 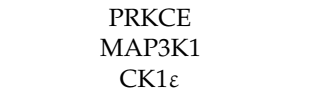 & 442 kinases \\
\hline Thiophene 48 [144] & 110 & $\begin{array}{c}22 \% \\
(5 \mu \mathrm{M})\end{array}$ & $\begin{array}{c}69 \% \\
(5 \mu \mathrm{M})\end{array}$ & $\begin{array}{c}1 \% \\
(5 \mu \mathrm{M})\end{array}$ & 100 & 70 & 40 & $\begin{array}{c}91 \% \\
(5 \mu \mathrm{M})\end{array}$ & ND & ND & - & 102 kinases \\
\hline 3A5 [145] & 51 & 68 & 346 & ND & 260 & ND & $\begin{array}{c}61 \% \\
(1 \mu \mathrm{M})\end{array}$ & inactive & inactive & inactive & $\mathrm{CK} 1 \gamma 2$ & $\sim 140$ kinases \\
\hline Cpd-2 [146] & 1.1 & 2.4 & ND & ND & ND & ND & ND & ND & ND & ND & $\begin{array}{l}\text { SRPK1 }=200 \\
\text { SRPK2 }=310 \\
\text { SRPK3 }=230\end{array}$ & 28 kinases \\
\hline
\end{tabular}


Table 2. Cont.

\begin{tabular}{|c|c|c|c|c|c|c|c|c|c|c|c|c|}
\hline \multirow[b]{2}{*}{ Compound } & \multicolumn{4}{|c|}{ CLKs } & \multicolumn{6}{|c|}{ Structurally Similar Kinases } & \multirow[t]{2}{*}{ Other Significant Targets } & \multirow[t]{2}{*}{ Kinases Screened } \\
\hline & CLK1 & CLK2 & CLK3 & CLK4 & DYRK1A & DYRK1B & DYRK2 & HIPK1 & HIPK2 & HIPK3 & & \\
\hline SRI-29329 [147] & 78 & 16 & $>1000$ & 86 & $\begin{array}{c}95 \% \\
(1 \mu \mathrm{M})\end{array}$ & ND & ND & ND & ND & ND & - & 29 kinases \\
\hline T3 $[135,148]$ & 0.67 & 15 & 110 & ND & 260 & 230 & ND & inactive & inactive & ND & - & 71 kinases \\
\hline Compound 25 [90] & 2 & 31 & inactive & 8 & 138 & 690 & inactive & inactive & inactive & inactive & - & 368 kinases \\
\hline TG693 [127] & 113 & $\begin{array}{c}85 \% \\
(1 \mu \mathrm{M})\end{array}$ & $\begin{array}{c}88 \% \\
(1 \mu \mathrm{M}) \\
\end{array}$ & ND & $\begin{array}{c}16 \% \\
(1 \mu \mathrm{M})\end{array}$ & ND & $\begin{array}{c}23 \% \\
(1 \mu \mathrm{M}) \\
\end{array}$ & inactive & ND & inactive & HASPIN & $\sim 313$ kinases \\
\hline Indazole1 [133] & 12 & 10 & 2250 & 12 & 73 & ND & ND & ND & ND & ND & - & 34 kinases \\
\hline KuWal151 [149] & 88 & 510 & inactive & 28 & inactive & inactive & inactive & ND & ND & ND & - & $\mathrm{IC}_{50}$ for 14 kinases \\
\hline T-025 [118] & $\begin{array}{c}4.8 \\
\left(\mathrm{~K}_{\mathrm{d}}\right)\end{array}$ & $\begin{array}{l}0.096 \\
\left(K_{d}\right)\end{array}$ & $\begin{array}{c}6.5 \\
\left(\mathrm{~K}_{\mathrm{d}}\right)\end{array}$ & $\begin{array}{l}0.61 \\
\left(\mathrm{~K}_{\mathrm{d}}\right)\end{array}$ & $\begin{array}{l}0.074 \\
\left(\mathrm{~K}_{\mathrm{d}}\right)\end{array}$ & $\begin{array}{c}1.5 \\
\left(\mathrm{~K}_{\mathrm{d}}\right)\end{array}$ & $\begin{array}{c}32 \\
\left(\mathrm{~K}_{\mathrm{d}}\right)\end{array}$ & $\begin{array}{c}55 \\
\left(\mathrm{~K}_{\mathrm{d}}\right)\end{array}$ & $\begin{array}{c}96 \\
\left(\mathrm{~K}_{\mathrm{d}}\right)\end{array}$ & $\begin{array}{c}5 \% \\
(0.3 \mu \mathrm{M})\end{array}$ & $\begin{array}{l}\text { HIPK4 } \\
\text { YSK4 } \\
\text { IRAK4 } \\
\text { FLT } \\
\text { ERK8 }\end{array}$ & 468 kinases \\
\hline CC-671 [137] & 300 & 6.3 & $\begin{array}{c}60 \% \\
(3 \mu \mathrm{M})\end{array}$ & ND & 104 & 157 & ND & $\begin{array}{c}97 \% \\
(3 \mu \mathrm{M})\end{array}$ & $\begin{array}{c}96 \% \\
(3 \mu \mathrm{M})\end{array}$ & $\begin{array}{c}92 \% \\
(3 \mu \mathrm{M})\end{array}$ & $\begin{array}{c}\text { TTK }=5 \\
\text { DYRK3 }=99 \\
\text { PhK } 1=136 \\
\text { TSSK1 }=452\end{array}$ & 225 kinases \\
\hline $\begin{array}{c}\text { Pyrido } \\
\text { [3,4-g]quinazoline } \\
\text { 9m [150] }\end{array}$ & 18 & ND & ND & ND & $\begin{array}{c}39 \% \\
(1 \mu \mathrm{M})\end{array}$ & ND & ND & ND & ND & ND & $\begin{array}{c}\text { CDK5 } \\
\text { CK1 } \\
\text { GSK3 }\end{array}$ & - \\
\hline SGC-CLK-1 [151] & 13 & 4 & 363 & 46 & ND & ND & ND & 50 & 42 & ND & $\begin{array}{c}\text { ERK8 } \\
\text { NEK7 } \\
\text { PIP5K2B } \\
\text { STK16 }\end{array}$ & 403 kinases \\
\hline SM08502 [76] & 8 & 1 & 22 & 1 & 1 & 1 & 3 & ND & 23 & 21 & $\begin{array}{l}\text { additional } 14 \text { kinases with } \\
\text { IC }_{50}<50 \mathrm{nM}\end{array}$ & 466 kinases \\
\hline MU1210 $[47,152]$ & 8 & 20 & Inactive & 12 & 213 & 956 & 1309 & 187 & 29 & 159 & $\begin{array}{c}\text { GSK3 } \alpha \\
\text { PIM1/1 } \\
\text { HASPIN }\end{array}$ & $\begin{array}{c}210 \\
\text { kinases }\end{array}$ \\
\hline AB1 [89] & ND & ND & ND & ND & ND & ND & ND & ND & ND & ND & $\begin{array}{c}\text { BTK }=2 \\
\text { hERGFR }=2\end{array}$ & ND \\
\hline $\begin{array}{c}\text { TCMDC-135051 } \\
{[130,131]}\end{array}$ & ND & $\begin{array}{c}17 \% \\
(1 \mu \mathrm{M})\end{array}$ & 40 & ND & $\begin{array}{c}71 \% \\
(1 \mu \mathrm{M})\end{array}$ & ND & $\begin{array}{c}99 \% \\
(1 \mu \mathrm{M})\end{array}$ & $\begin{array}{c}83 \% \\
(1 \mu \mathrm{M})\end{array}$ & $\begin{array}{c}56 \% \\
(1 \mu \mathrm{M})\end{array}$ & $\begin{array}{c}93 \% \\
(1 \mu \mathrm{M})\end{array}$ & $\begin{array}{c}\text { MNK1 } \\
\text { MAP4K3 } \\
\text { CAMKKb } \\
\text { CDK9 } \\
\text { IRAK1 } \\
\text { TGFBR1 } \\
\text { PHK }\end{array}$ & 140 kinases \\
\hline
\end{tabular}


TG003 (Figure 7) represents one of the first CLK inhibitors (published in 2004) [64] and its activities in biochemical assays have been determined several times with slightly different results $[64,134,153]$. TG003 is active also in cell-based assays and in vivo. In the cell, the inhibitor can elicit suppression of the exon skipping and serine/arginine-rich protein phosphorylation, dissociation of nuclear speckles, and Clk1/Sty-dependent alternative splicing [64]. A broader screening against 402 kinases revealed significant off-target activities, indicating that the use of TG003 as a chemical probe is likely problematic [134]. Despite this fact, the compound is still being widely used in life sciences as a CLK inhibitor.

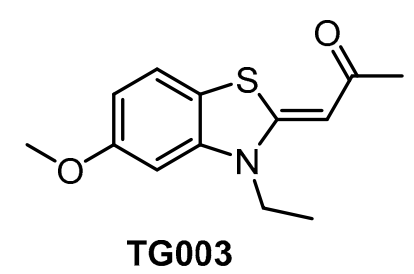

Figure 7. Structure of the compound TG003.

The quinazoline-based inhibitor ML106 (Figure 8) was published in 2009 [134]. ML106 (analog of ML167) inhibits CLK1/2/3/4 with $K_{d}$ values of $37 \mathrm{nM}, 680 \mathrm{nM}, 470 \mathrm{nM}$, and $50 \mathrm{nM}$, respectively. ML106 was profiled in a panel of 402 kinases; detailed results of the profiling are not available, but significant off-targets are DYRK1A, DYRK1B, and EGFR with $\mathrm{K}_{\mathrm{d}}$ values $27 \mathrm{nM}, 430 \mathrm{nM}$, and $230 \mathrm{nM}$, respectively [134]. Of note, the published $\mathrm{IC}_{50}$ values $\left(C L K 1 \mathrm{IC}_{50}=59 \mathrm{nM}, \mathrm{CLK} 2 \mathrm{IC}_{50}=1902 \mathrm{nM}\right.$, CLK3 IC $50=6936 \mathrm{nM}$, CLK4 IC $50=39 \mathrm{nM}$ ) do not correlate well with the $\mathrm{K}_{\mathrm{d}}$ values above [153]. Other quinazoline-based analogs were also profiled in panels of 402 or 442 kinases, which revealed their very good selectivity [153]. Some of them were further tested in the Caco-2 permeability assay or for cellular efflux, suggesting that selected analogs might be used as tool compounds for cell-based experiments; however, no cellular activities have been published thus far [153].

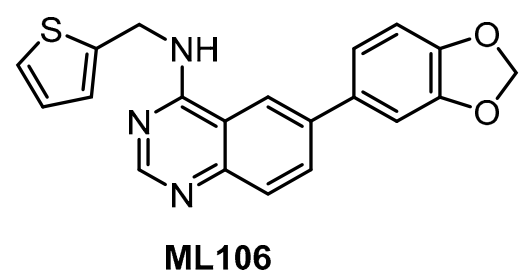

Figure 8. Structure of the compound ML106.

To our best knowledge, the compound ML167 (Figure 9) represents the most selective CLK4 inhibitor $\left(\mathrm{IC}_{50}=136 \mathrm{nM}\right)$, according to the data obtained in biochemical screening (Table 2) [153]. Although ML167 is not the most potent CLK inhibitor, it is selective with respect to other family members CLK1/2/3 and (importantly) DYRK1A/B (Table 2). The selectivity was determined by testing in a panel of 442 kinases [153]; unfortunately, neither the results of this kinome-wide screening nor information about additional off-targets are available. Likewise, there are no data on the compound's activity in the cell. Therefore, any utilization of ML167 as a chemical probe for CLK4 should be considered with caution. Many ML167 analogs with different CLK and DYRK selectivity profiles have been synthesized; more detailed information can be found in the original report [153].

CX-4945 (Figure 10) has been primarily reported, marketed, and used as a highly selective and potent inhibitor of CK2 since 2011 [140]. However, CX-4945 strongly inhibits also CLKs and DYRK1A [133]. In addition, it interacts significantly with other kinases such as HIPKs or PIM kinases $[133,139]$. 


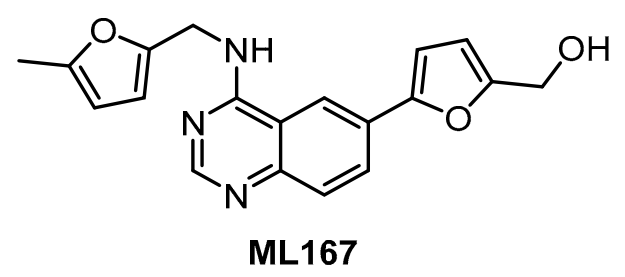

Figure 9. Structure of the compound ML167.

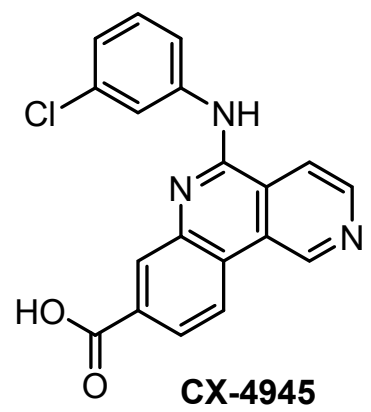

Figure 10. Structure of the compound CX-4945.

KH-CB19 (Figure 11), published in 2011, was among the first CLK inhibitors found to be superior to TG003 [141]. Based on $\mathrm{IC}_{50}$ values obtained in biochemical assays, the compound is a potent inhibitor of CLK1 and DYRK1A. The selectivity profile, evaluated by thermal shift assay against 106 kinases, indicates also strong inhibition of CLK4 and some off-target activity against PIM1/3 and SGK085 [141]. KH-CB19 also exhibits CLK inhibitory activity in the cell [141]. Utilization of KH-CB19 as a chemical probe should be done with caution and ideally after further profiling across the kinome. The utilization in vivo might be problematic since the molecule contains potentially labile ester functionality.<smiles>CCOC(=O)c1c(/C(C#N)=C\N)c2ccc(Cl)c(Cl)c2n1C</smiles>

\section{KH-CB19}

Figure 11. Structure of the compound KH-CB19.

Leucettine 41 (Figure 12) was developed by modification of the natural product Leucettamine B [142]. The compound strongly inhibits CLK1/4 and DYRK1A/B [142]. However, the data for DYRK2 are rather inconsistent $\left(\mathrm{IC}_{50}=73 \mathrm{nM} ; \mathrm{Kd}=450 \mathrm{nM}\right)$, since for a competitive inhibitor, $\mathrm{K}_{\mathrm{d}}$ is typically smaller than $\mathrm{IC}_{50}$ [142]. Leucettine 41 is only weakly active towards CLK2/3 (Table 3). Testing in a panel of 402 kinases at $10 \mu \mathrm{M}$ concentration revealed a good selectivity profile; additional off-targets being HIPK1/3 and GSK3A [142]. Interestingly, GSK3A inhibition in the cell was not observed while in cell inhibition of DYRK1A was confirmed [142]. Leucettine 41 could be a useful chemical probe, but additional profiling would be desirable (such as determination of the CLK engagement in the cell or in cell activity against HIPKs). 


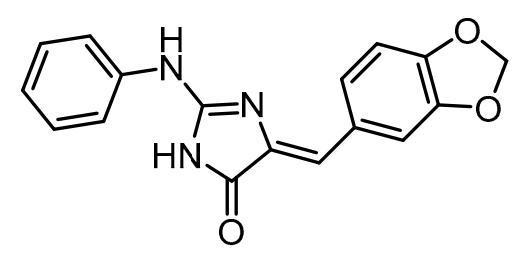

Leucettine 41

Figure 12. Structure of Leucettine 41.

Table 3. $\mathrm{K}_{\mathrm{d}}$ values for kinases significantly inhibited by Leucettine 41 at $10 \mu \mathrm{M}$ concentration [142].

\begin{tabular}{cc}
\hline Kinases & Kd (nM) \\
\hline CLK4 & 70.0 \\
DYRK1A & 7.8 \\
CLK1 & 75.0 \\
DYRK2 & 450.0 \\
HIPK1 & 320.0 \\
CLK3 & 1100.0 \\
IRAK1 & 930.0 \\
HIPK3 & 230.0 \\
DYRK1B & 140.0 \\
CLK2 & 360.0 \\
TAOK1 & 1700.0 \\
TYK2 & n.t \\
GSK3A & 550.0 \\
\hline
\end{tabular}

ML315 (Figure 13) was published in 2013 as a selective CLK/DYRK1A inhibitor [143]. The compound inhibits both CLK1/4 with $\mathrm{IC}_{50}$ of $68 \mathrm{nM}$ and, somewhat more weakly, CLK2 and DYRK1A ( $\left(\mathrm{IC}_{50}=231 \mathrm{nM}\right.$ and $282 \mathrm{nM}$, respectively) [143]. A very good selectivity profile was confirmed by screening in a panel of 442 kinases whereby PRKCE was revealed as the only off-target showing $<10 \%$ residual activity at $10 \mu \mathrm{M}$ concentration [143]. Although the microsomal stability of ML315 is low, it has appropriate physicochemical properties for in cell studies and represents a useful chemical probe for CLK/DYRK biology [143].<smiles>Clc1cc(Cl)cc(CNc2ncncc2-c2ccc3c(c2)OCO3)c1</smiles>

\section{ML315}

Figure 13. Structure of the compound ML315.

Based on the natural product Harmine, which is moderately active against CLK1 and DYRK kinases, Thiophene 48 (Figure 14) has been identified as a CLK1/DYRK1/DYRK2 inhibitor [144]. Profiling in a panel of 102 kinases at $5 \mu \mathrm{M}$ concentration revealed decent selectivity, with strong inhibition of CLK4 [144]. In cell activity has been demonstrated as well [144]. Further profiling would be necessary to determine whether Thiophene 48 fulfills the criteria for a quality chemical probe (for CLK1/4 and DYRKs). 
<smiles>c1cncc(-c2csc(-c3cncs3)c2)c1</smiles>

Thiophene 48

Figure 14. Structure of the compound Thiophene 48.

The compound 3A5 (Figure 15) was reported in 2015 as a CLK inhibitor with a novel benzobisthiazole scaffold [145]. Furthermore, 3A5 has a strong affinity towards CLK1/2 and only moderate activity against CLK3 and DYRK1A. Importantly, it is inactive against structurally similar HIPKs and only weakly active against DYRK2. Unfortunately, the selectivity was determined in a panel of only 142 kinases at $1 \mu \mathrm{M}$ concentration and the CLK4 and DYRK1B inhibitory activities have not been determined at all. Although 3A5 shows some selectivity for CLKs vs. DYRKs, its utilization as a probe cannot be recommended as its in cell activities have not been demonstrated thus far.<smiles>CC(C)(C)C</smiles>

Figure 15. Structure of the compound 3A5.

The CLK1/2 inhibitor cpd-2 (Figure 16) was published in 2015, together with two analogs cpd-1 and cpd-3 [146]. Cpd-2 possesses high selectivity for CLK1/2 vs. SRPK1/2/3. However, the inhibitors have been screened against only 28 kinases. Therefore, the compound cannot be recommended as a chemical probe at this point.

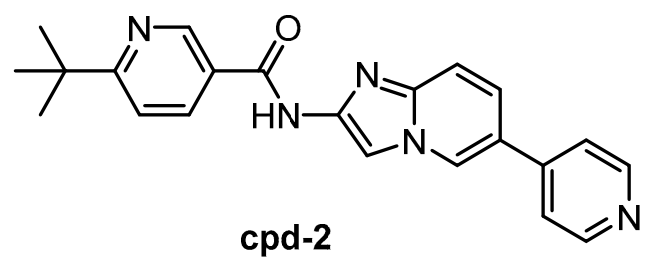

Figure 16. Structure of the compound cpd-2.

The CLK1/2/4 inhibitor SRI-29329 (Figure 17) was published in 2016, together with its analogs [147]. Some members of the series show dual inhibitory activity towards CLK1/24 and CDK1/4 (such as CGP-74514A, which is incorrectly being sold and used as a selective CDK1 inhibitor) [147]. Of note, SRI-29329 is inactive against DYRK1A [147]. Since SRI-29329 has been profiled against only 29 kinases, it is not recommended to use it as a chemical probe [147].<smiles>CC(C)n1cnc2c(Nc3cccc(Cl)c3)nc(N[C@H]3CCCCC3N)nc21</smiles>

SRI-29329

Figure 17. Structure of the compound SRI-29329. 
The pan-CLK inhibitor T3 (Figure 18), based on cpd-1/2/3, was published in 2017 [135]. The compound is a potent inhibitor of CLK1, CLK2, and CLK3-the IC $_{50}$ values determined in biochemical assays are $0.67 \mathrm{nM}, 15 \mathrm{nM}$, and $110 \mathrm{nM}$, respectively. T3 exhibits good selectivity against DYRK1A and DYRK1B ( $\mathrm{IC}_{50}=260 \mathrm{nM}$ and $230 \mathrm{nM}$, respectively) [135]. Other significant off-targets have not been found thus far. However, the compound has been screened against only 71 kinases at $0.1 \mu \mathrm{M}$ and $1 \mu \mathrm{M}$ concentrations [135]. Cellular activity of T3 has been confirmed in several assays; its cellular potency based on NanoBRET assay is $4 \mathrm{nM}, 17 \mathrm{nM}$, and $2 \mathrm{nM}$ towards CLK1/2/4, and $32 \mathrm{nM}$ and $67 \mathrm{nM}$ towards DYRK1A/B, respectively [148]. It has been also shown that T3 induces a decrease in the phosphorylation state of SRSF protein in a time- and dose-dependent manner at 10-1000 nM concentration in HeLa cells [148]. Importantly, the testing was performed in parallel with a negative control compound [148]. As a result, T3 can be recommended as a quality chemical probe for CLK1/2/4, ideally in combination with another selective inhibitor.

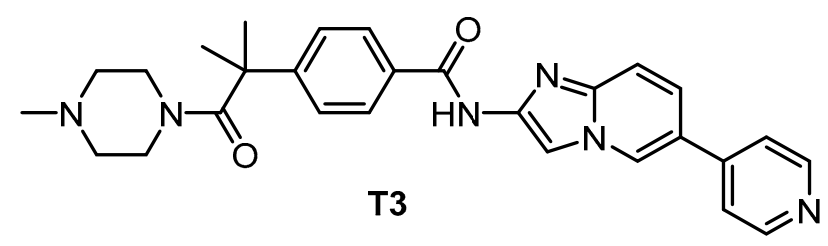

Figure 18. Structure of the compound T3.

In 2017, Compound 25 (Figure 19) was published as a CLK1 inhibitor [90]. While the compound exhibits the highest potency towards CLK1 $\left(\mathrm{IC}_{50}=2 \mathrm{nM}\right)$, it is also highly active towards CLK2 and CLK4 $\left(\mathrm{IC}_{50}=31 \mathrm{nM}\right.$ and $8 \mathrm{nM}$, respectively), but practically inactive against CLK3. The most significant off-target outside of the CLK subfamily is DYRK1A $\left(\mathrm{IC}_{50}=138 \mathrm{nM}\right)$. Compound $25^{\prime} \mathrm{s}$ high in vitro selectivity was confirmed in the panel of 387 human protein kinases at $10 \mu \mathrm{M}$ concentration. The cellular activity was investigated via the effect on SR protein phosphorylation. In addition, Compound 25 induced autophagy in BNL CL.2 and SKOV-3 (human ovarian cancer cell line) cell lines. The pharmacokinetic profile (in mice) is also available in the original publication [90]. Unfortunately, an inactive control compound as well as the determination of cellular target engagement are missing. Compound 25 can be considered a useful tool compound for CLK1/2/4, but it would be desirable to supplement it with an inactive control compound.<smiles>CC(c1ccc(F)cc1)n1nnc2cnc3ccc(-c4ccc5ocnc5c4)cc3c21</smiles>

Compound 25

Figure 19. Structure of Compound 25.

The orally available CLK inhibitor TG693 (Figure 20) was reported in 2017 [127]. The compound shows good selectivity, based on screening against a panel of 313 kinases at $1 \mu \mathrm{M}$ concentration; however, its in vitro activity towards CLK1 $\left(\mathrm{IC}_{50}=113 \mathrm{nM}\right.$, biochemical assay) is somewhat lower compared to other known CLK inhibitors. TG693 exhibits only a weak affinity for CLK2/3; and to our knowledge, the activity against CLK4 has not been determined. The most significant off-targets are HASPIN, DYRK1a, and DYRK2, with residual activities of $7 \%, 16 \%$, and $23 \%$, respectively, upon treatment with 
$1 \mu \mathrm{M}$ TG693. Although TG693 does not fulfill the criteria for a quality probe, it still might be one of the best tools for selective inhibition of CLK1. TG693 exhibits activity in the cell and in vivo and its pharmacokinetic profile in mice is superior to that of TG003 [127].

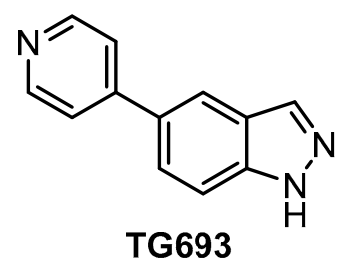

Figure 20. Structure of the compound TG693.

Indazole1 (Figure 21) was published recently as an inhibitor of CLKs, active in vivo [133]. The compound potently inhibits CLK1/2/4 and DYRK1A in vitro. However, the data on the selectivity of Indazole1 are not sufficient, since the compound has been profiled against only 34 kinases [133]. Therefore, its use as a chemical probe should be avoided at this point.<smiles>Cc1n[nH]c2ccc(-c3cncc(OC[C@H](N)CC(C)C)c3)cc12</smiles>

Indazole1

Figure 21. Structure of the compound Indazole1.

The potent CLK inhibitor KuWal151 (Figure 22) was published in 2018 [149]. The determined $\mathrm{IC}_{50}$ values for CLK1/2/4 are $88 \mathrm{nM}, 510 \mathrm{nM}$ and $28 \mathrm{nM}$, respectively [149]. Interestingly, KuWal151 is inactive towards DYRK1A/B and DYRK2 [149]. However, the compound's selectivity profile across the kinome has not been published thus far and only $\mathrm{IC}_{50}$ values for 14 kinases have been reported. The antiproliferative activity of KuWal151 was demonstrated in a panel of 57 cancer cell lines-in most cases, the compound was active at sub-micromolar concentrations [149].

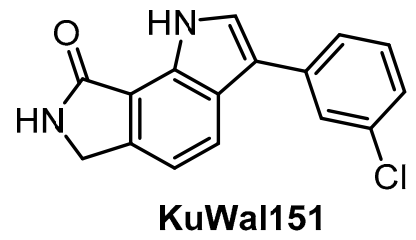

Figure 22. Structure of the compound KuWal151.

T-025 (Figure 23) was reported in 2018 as a potent pan-CLK inhibitor, which (unlike most CLK inhibitors) exhibits also high potency against CLK3 $\left(\mathrm{K}_{\mathrm{d}}=3.5 \mathrm{nM}\right)$ [118]. The analysis of the crystal structure revealed that the inhibitor interacts with Glu244 and Leu246 in the CLK2 hinge region [118]. The compound's good selectivity profile was revealed via screening against 468 kinases at $0.3 \mu \mathrm{M}$ concentration [118]. In comparison to the inhibitor T3, T-025 exhibits lower selectivity towards DYRK1A/B and it inhibits also DYRK2, HIPKs, IRAK4, and YSK4 with $\mathrm{K}_{\mathrm{d}}<100 \mathrm{nM}$ [118]. In addition, T-025 exhibits cellular and in vivo activity and according to the authors, it represents the first reported CLK inhibitor with anti-tumor efficacy [118]. Unfortunately, the cellular potency and selectivity have not been determined. Although T-025 does not fulfill the criteria for a quality chemical probe for CLKs, still it might be a useful tool compound in some cases, considering its potency against CLK3 and in vivo activity. 


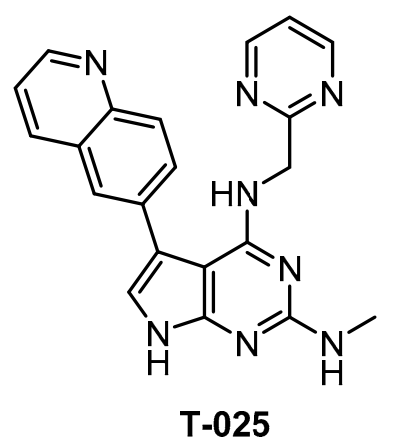

Figure 23. Structure of the compound T-025.

In 2018, CC-671 (Figure 24) was reported as CLK/TTK inhibitor [137]. Interestingly, this compound exhibits some selectivity for CLK2 $\left(\mathrm{IC}_{50}=6 \mathrm{nM}\right)$ vs. CLK1 $\left(\mathrm{IC}_{50}=300 \mathrm{nM}\right)$ and especially CLK3 (60\% residual activity at $3 \mu \mathrm{M}$ concentration), based on biochemical assay [137]. Unfortunately, the compound's ability to inhibit CLK4 is unknown as well as its selectivity profile in the cell. Although CC-671 does not fulfill the criteria for a quality probe, further profiling (and potentially structural modifications) may potentially lead to an interesting tool compound for specific inhibition of CLK2. In addition, CC-671 has been used in various cell-based and in vivo assays where it elicited growth inhibition and induction of apoptosis in various types of cancer cells [137]. The in vivo efficacy was shown in two cell line-derived and one patient tumor-derived xenograft models of triple-negative breast cancer. This therapeutic effect was credited to dual inhibition of CLK2/TTK [137].

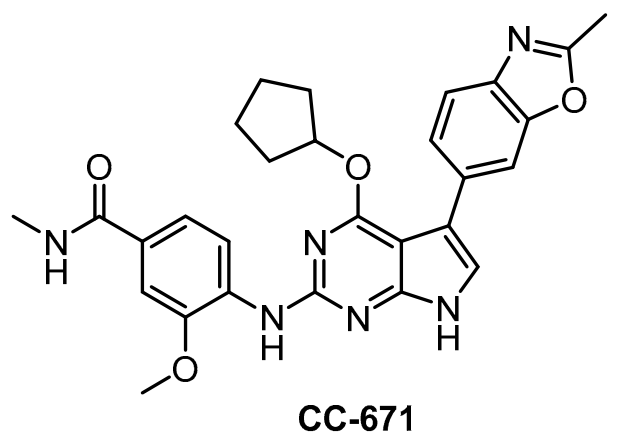

Figure 24. Structure of the compound CC-671.

The family of pyrido[3,4-g]quinazoline-based compounds inhibiting CLK1, DYRK1A, CDK5, CK1, and GSK3 was published in 2019 [150]. More than 20 different analogs with varying selectivity were described in the report. The most active compound towards CLK1 is the pyrido[3,4-g]quinazoline $9 \mathrm{~m}$ (Figure 25), exhibiting $\mathrm{IC}_{50}$ of $18 \mathrm{nM}$ [150]. The inhibitory activities against DYRK1A, CDK5, CK1, and GSK3 were determined at fixed concentrations $(10 \mu \mathrm{M}$ and $1 \mu \mathrm{M})$; the residual kinase activities at $1 \mu \mathrm{M}$ concentration are: DYRK1A $=39 \%, \mathrm{CDK} 5=73 \%, \mathrm{CK} 1=98 \%$, and GSK3 $=70 \%$. However, more detailed information about the kinome-wide selectivity is not available [150].<smiles>CNc1ncc2cc3cnccc3c([N+](=O)[O-])c2n1</smiles>

\section{Pyrido[3,4-g]quinazoline 9m}

Figure 25. Structure of the compound pyrido[3,4-g]quinazoline $9 \mathrm{~m}$. 
The SGC developed CLK1/2/4 inhibitor SGC-CLK-1 (Figure 26) in collaboration with Luceome Biotechnologies [151]. The compound's activity towards CLK1/2/4 was determined in biochemical assays and confirmed in the cell by NanoBRET assay (in cell $\mathrm{IC}_{50}=165 / 100 / 70 \mathrm{nM}$ for CLK1/2/4, respectively) [151]. SGC-CLK-1 was tested in a panel of 403 kinases and the potential off-targets (HIPK1/2, ERK8, NEK7, PIP5K2B, STK16) were then evaluated in NanoBRET assay [151]. As a result, the only off-target found to be partially inhibited in the cell was STK16 [151]. A negative control compound was tested in parallel with SGC-CLK-1. This inhibitor represents an excellent tool compound for cell-based experiments and it can be recommended as a quality probe for CLK1/2/4.<smiles>COc1cc(Nc2nccc(-c3cnn4nc(OC)ccc34)n2)cc(C(F)(F)F)c1</smiles>

SGC-CLK-1

Figure 26. Structure of the compound SGC-CLK-1.

SM08502 (Figure 27) represents the first CLK inhibitor that entered clinical trials [76]. The exact structure of this isoquinoline-based compound has not been disclosed so far. Since the compound inhibits several off-targets (19 additional kinases with $\mathrm{IC}_{50}<50 \mathrm{nM}$ ), it is not suitable for utilization as a chemical probe. On the other hand, its favorable pharmacological properties and anti-tumor efficacy enabled the initiation of Phase I of clinical trials using SM08502 in patients with advanced solid tumors [76]. It has been suggested that the compound's pan-CLK inhibitory activity is substantial for sufficient in cell and in vivo anti-tumor activity [76]. Particularly, it seems to be important that SM08502 inhibits also CLK3, which is often not the case for other CLK inhibitors [76].<smiles>[R16][R4]1=Cc2c(cnc(NC([R])=O)c2[R7])C=C[Y10]1</smiles>

Figure 27. Generic structure of the compound SM08502.

In vitro profiling of a series of 3,5-disubstituted furo[3,2-b]pyridines revealed highly potent and selective CLK1/2/4 inhibitors [47]. The analog most active in the cell, compound MU1210 (Figure 28), was profiled in greater detail using radioenzymatic and NanoBRET assays, in parallel with the negative control MU140 (Table 4).

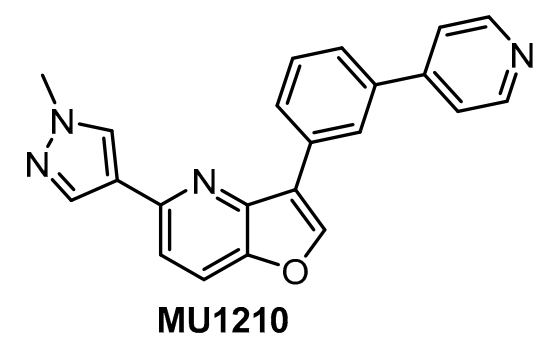

Figure 28. Structure of the compound MU1210. 
HIPK2 was revealed as the most significant off-target in vitro (biochemical assay); however, it was not inhibited by MU1210 in the cell (based on the NanoBRET assay). Similarly, the NanoBRET assay demonstrated only very weak activity against DYRKs (typical problematic off-targets of CLK inhibitors) and GSK $3 \alpha$, and overall excellent selectivity profile in the cell. Additional weak off-targets determined in the primary biochemical screen were GSK3 $\alpha$, PIM1, PIM2, and HASPIN exhibiting residual activity of $10 \%, 16 \%, 19 \%$, and $26 \%$, respectively, at $1 \mu \mathrm{M}$ concentration of MU1210. MU1210 exhibited anti-tumor activity in MCF7, MDA MB 231, and MCF10A breast cancer cell lines (with EC 50 values of 1.1, 1.3, and $1.5 \mu \mathrm{M}$, respectively) as well as in HeLa, U2OS, PANC1, HEK293T, AGP01, and MEF cancer cell lines. In addition, MU1210 affected phosphorylation of SR protein in HeLa cells (while the negative control MU140 had no effect) and modulated alternative mRNA splicing of MDM4 [47,152].

Overall, the compound MU1210 is a potent CLK1/2/4 inhibitor in vitro as well as in the cell that exhibits excellent selectivity profile across the kinome, fulfilling the criteria for a quality chemical probe [154-156]. The compound has been recommended by the Structural Genomic Consortium as the state-of-the-art tool compound for CLK1/2/4 [152].

The irreversible inhibitor of Trypanosoma brucei CLK1, compound AB1 (Figure 29), was published very recently [89]. The phenotypic screen of the T. brucei bloodstream forms with the Novartis kinase-focused inhibitor library (2.3 million compounds) identified compounds with pan-kinetoplastid activity. Further testing against $T$. brucei mutants that overexpress known essential protein kinases revealed CLK1 as the primary target and subsequent SAR studies provided the optimized compound AB1. The irreversible competitive inhibition of CLK1 is provided by the Michael acceptor acryl amide motif, which forms a covalent bond with the $\mathrm{C} 215$ residue in the active site cavity. That residue is not present in human CLK1, thereby providing the compound's selectivity for Trypanosoma brucei CLK1 over the human variant. AB1 exhibits also potent inhibitory activity against hERGFR and BTK kinases ( $\mathrm{IC}_{50}$ values are $2 \mathrm{nM}$ and $2 \mathrm{nM}$, respectively); additional information on the selectivity has not been published yet [89].

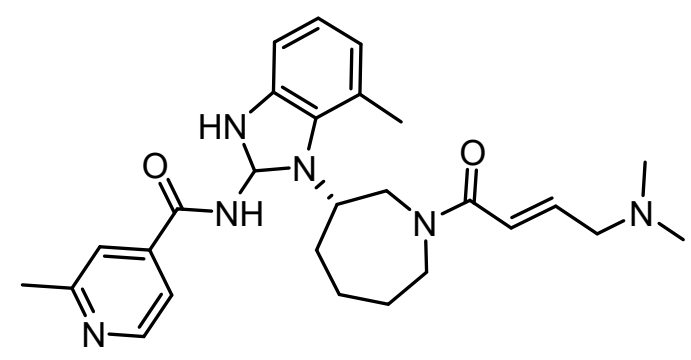

AB1

Figure 29. Structure of the compound AB1.

The compound Lead-30 as well as its precursor, the screening hit TCMDC-135051 (Figure 30), were published very recently $[130,131]$. Both TCMDC-135051 and Lead-30 inhibit PfCLK3 in Plasmodium falciparum $\left(\mathrm{IC}_{50}=40 \mathrm{nM}\right.$ and $19 \mathrm{nM}$, respectively). Screening of TCMDC-135051 (at $1 \mu \mathrm{M}$ concentration) against 140 kinases revealed 14 additional kinases showing residual activity below 20\%. TCMDC-135051 was found to be also active in vivo-its dose-dependent efficacy was demonstrated in P. berghei-infected mice [130]. These results make TCMDC-135051 and Lead-30 good candidates for further development; however, the compounds have not been sufficiently profiled for selectivity to be utilized as quality chemical probes. 


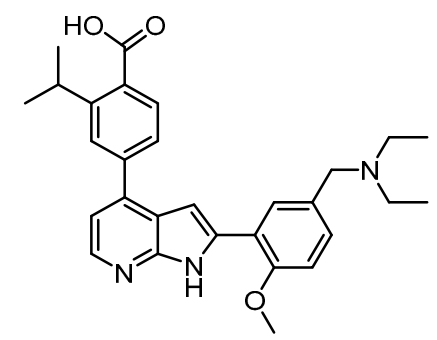

TCMDC-135051

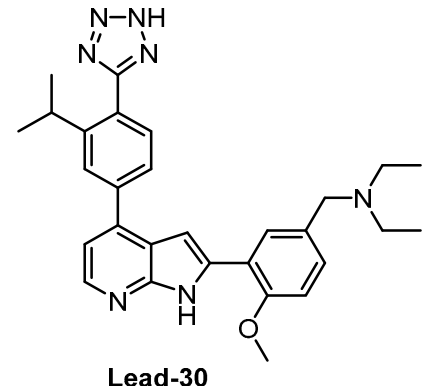

Lead-30

Figure 30. Structures of the compounds TCMDC-135051 and Lead-30.

The chemical structures of the CLK inhibitors reviewed above are collectively represented in Figure 31.<smiles>CCN1C(=CC(C)=O)Sc2ccc(OC)cc21</smiles>

TG003<smiles>c1csc(CNc2ncnc3ccc(-c4ccc5c(c4)OCO5)cc23)c1</smiles>

ML106<smiles>Cc1ccc(CNc2ncnc3ccc(-c4ccc(CO)o4)cc23)o1</smiles>

ML167<smiles>Clc1cc(Cl)c(CNc2ncncc2-c2ccc3c(c2)OCO3)c(Cl)c1</smiles>

ML315<smiles>CC(C)n1cnc2c(Nc3cccc(Cl)c3)nc(N[C@@H]3CCCCC3N)nc21</smiles>

SRI-29329 TG693
3A5<smiles>O=C1NC(Nc2ccccc2)=N/C1=C\c1ccc2c(c1)OCO2</smiles>

Leucettine 41

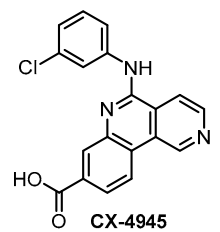<smiles>c1cncc(-c2csc(-c3cncs3)c2)c1</smiles>

Thiophene 48

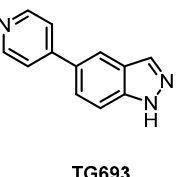

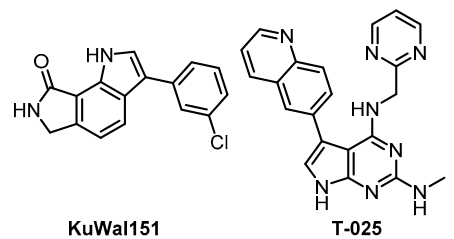

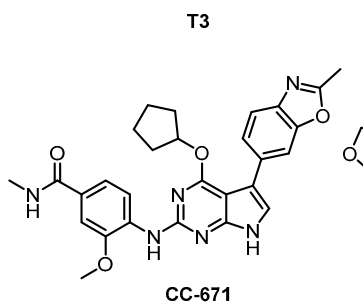<smiles>CC(Nc1cccc2cc(-c3ccccc3)ccc12)c1ccc(F)cc1</smiles>

Indazole1

KuWal151

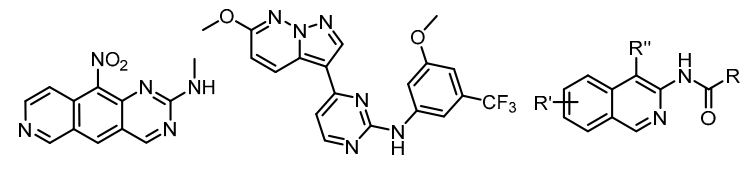<smiles>Cn1cc(-c2ccc3occ(-c4cccc(-c5ccncc5)c4)c3n2)cn1</smiles>

MU1210<smiles>Cc1cc(C(=O)NC2Nc3cccc(C)c3N2C2CCCCN(C(=O)/C=C/CN(C)C)C2)ccn1</smiles>

AB1<smiles>CCN(CC)Cc1ccc(OC)c(-c2cc3c(-c4ccc(C(=O)O)c(C(C)C)c4)ccnc3[nH]2)c1</smiles>

TCMDC-135051

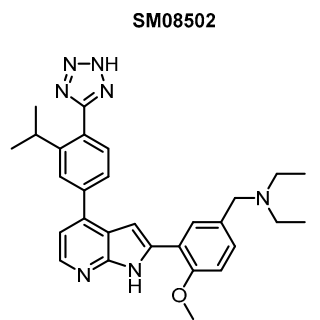

Lead-30

Figure 31. Chemical structures of the reviewed CLK inhibitors. 
Table 4. Biochemical and cellular activity of MU1210 and negative control MU140. The cellular $\mathrm{K}_{\mathrm{i}}$ values were determined by NanoBRET assays in HEK293T cells.

\begin{tabular}{|c|c|c|c|c|}
\hline \multirow[t]{2}{*}{ Kinase } & \multicolumn{2}{|c|}{ MU1210 Activity [nM] } & \multicolumn{2}{|c|}{$\begin{array}{l}\text { MU140 Activity [nM] } \\
\text { (Negative Control) }\end{array}$} \\
\hline & Biochemical $\mathrm{IC}_{50}$ & Cellular $\mathbf{K}_{\mathbf{i}}$ & Biochemical IC 50 & Cellular $\mathbf{K}_{\mathbf{i}}$ \\
\hline CLK1 & 8 & 84 & $>3000$ & $>10,000$ \\
\hline CLK2 & 20 & 91 & $>10,000$ & $>10,000$ \\
\hline CLK3 & $>3000$ & - & $>3000$ & - \\
\hline CLK4 & 12 & 23 & $>10,000$ & $>10,000$ \\
\hline DYRK1A & 213 & 6580 & $>3000$ & $>10,000$ \\
\hline DYRK1B & 956 & $>10,000$ & $>3000$ & $>10,000$ \\
\hline DYRK2 & 1309 & 1700 & $>10,000$ & $>10,000$ \\
\hline HIPK1 & 187 & - & $>10,000$ & - \\
\hline HIPK2 & 29 & $>10,000$ & $>10,000$ & - \\
\hline HIPK3 & 159 & - & $>3000$ & - \\
\hline HIPK4 & - & 5410 & - & - \\
\hline
\end{tabular}

\section{Conclusions}

Over the last two decades, a growing number of studies not only elucidated various aspects of the relatively complex biology of CLKs but also pre-clinically investigated their therapeutic potential. Some of the recently discovered structurally diverse small-molecule CLK inhibitors (summarized in this review) demonstrate sufficient selective activity to fulfill the criteria for quality chemical biology probes. The use of those selective compounds will very likely help further investigate different aspects of the CLK biology, including the role of the individual isoforms and therapeutic potential of their specific inhibition, which may be important in some contexts. The first CLK inhibitor SM08502 that entered clinical trials quite recently (and other compounds that are likely to follow) will demonstrate whether and how inhibition of CLKs can be used for the development of novel medications.

Author Contributions: Writing—original draft preparation, P.M.M., V.N. and K.P.; writing—review and editing, P.M.M., V.N. and K.P.; funding acquisition, K.P. All authors have read and agreed to the published version of the manuscript.

Funding: The research was funded by the following sources: European Structural and Investment Funds, Operational Programme Research, Development and Education, Preclinical Progression of New Organic Compounds with Targeted Biological Activity (Preclinprogress)-CZ.02.1.01/0.0/0.0/16_025/0007381, project no. LQ1605 from the National Program of Sustainability II (MEYS CR), the project CZ-OPENSCREEN: National Infrastructure for Chemical Biology (LM2015063), and Bader Philanthropies.

Conflicts of Interest: The authors declare no conflict of interest.

\section{References}

1. Roskoski, R. A Historical Overview of Protein Kinases and Their Targeted Small Molecule Inhibitors. Pharmacol. Res. 2015, 100, 1-23. [CrossRef] [PubMed]

2. Haar, E.; Walters, W.; Pazhanisamy, S.; Taslimi, P.; Pierce, A.; Bemis, G.; Salituro, F.; Harbeson, S. Kinase Chemogenomics: Targeting the Human Kinome for Target Validation and Drug Discovery. Mini-Rev. Med. Chem. 2004, 4, 235-253. [CrossRef] [PubMed]

3. Modi, V.; Dunbrack, R.L. Defining a New Nomenclature for the Structures of Active and Inactive Kinases. Proc. Natl. Acad. Sci. USA 2019, 116, 6818-6827. [CrossRef] [PubMed]

4. Cohen, P. Protein Kinases-the Major Drug Targets of the Twenty-First Century? Nat. Rev. Drug Discov. 2002, 1, 309. [CrossRef] 
5. Ardito, F.; Giuliani, M.; Perrone, D.; Troiano, G.; Muzio, L.L. The Crucial Role of Protein Phosphorylation in Cell Signaling and Its Use as Targeted Therapy (Review). Int. J. Mol. Med. 2017, 40, 271-280. [CrossRef]

6. Fleuren, E.D.G.; Zhang, L.; Wu, J.; Daly, R.J. The Kinome "at Large" in Cancer. Nat. Rev. Cancer 2016, 16, 83-98. [CrossRef]

7. Roskoski, R. Properties of FDA-Approved Small Molecule Protein Kinase Inhibitors: A 2020 Update. Pharmacol. Res. 2020, 152, 104609. [CrossRef]

8. Berndt, N.; Karim, R.M.; Schönbrunn, E. Advances of Small Molecule Targeting of Kinases. Curr. Opin. Chem. Biol. 2017, 39, 126-132. [CrossRef]

9. Deng, Y.N.; Bellanti, J.A.; Zheng, S.G. Essential Kinases and Transcriptional Regulators and Their Roles in Autoimmunity. Biomolecules 2019, 9, 145. [CrossRef]

10. Wu, P.; Nielsen, T.E.; Clausen, M.H. Small-Molecule Kinase Inhibitors: An Analysis of FDA-Approved Drugs. Drug Discov. Today 2016, 21, 5-10. [CrossRef]

11. Fedorov, O.; Müller, S.; Knapp, S. The (Un)Targeted Cancer Kinome. Nat. Chem. Biol. 2010, 6, $166-169$. [CrossRef] [PubMed]

12. Lind, J.; Czernilofsky, F.; Vallet, S.; Podar, K. Emerging Protein Kinase Inhibitors for the Treatment of Multiple Myeloma. Expert Opin. Emerg. Drugs 2019, 24, 133-152. [CrossRef] [PubMed]

13. Xu, J.; Wang, P.; Yang, H.; Zhou, J.; Li, Y.; Li, X.; Xue, W.; Yu, C.; Tian, Y.; Zhu, F. Comparison of FDA Approved Kinase Targets to Clinical Trial Ones: Insights from Their System Profiles and Drug-Target Interaction Networks. BioMed Res. Int. 2016, 2016, 2509385. [CrossRef] [PubMed]

14. Ferguson, F.M.; Gray, N.S. Kinase Inhibitors: The Road Ahead. Nat. Rev. Drug Discov. 2018, 17, $353-377$. [CrossRef] [PubMed]

15. Jeong, S. SR Proteins: Binders, Regulators, and Connectors of RNA. Mol. Cells 2017, 40, 1. [CrossRef] [PubMed]

16. Corkery, D.P.; Holly, A.C.; Lahsaee, S.; Dellaire, G. Connecting the Speckles: Splicing Kinases and Their Role in Tumorigenesis and Treatment Response. Nucleus 2015, 6, 279-288. [CrossRef]

17. Chaudhary, S.; Khokhar, W.; Jabre, I.; Reddy, A.S.N.; Byrne, L.J.; Wilson, C.M.; Syed, N.H. Alternative Splicing and Protein Diversity: Plants versus Animals. Front. Plant Sci. 2019, 10, 708. [CrossRef]

18. Fackenthal, J.D.; Godley, L.A. Aberrant RNA Splicing and Its Functional Consequences in Cancer Cells. Dis. Model. Mech. 2008, 1, 37-42. [CrossRef]

19. Czubaty, A.; Piekiełko-Witkowska, A. Protein Kinases That Phosphorylate Splicing Factors: Roles in Cancer Development, Progression and Possible Therapeutic Options. Int. J. Biochem. Cell Biol. 2017, 91, 102-115. [CrossRef]

20. Bates, D.O.; Cui, T.-G.; Doughty, J.M.; Winkler, M.; Sugiono, M.; Shields, J.D.; Peat, D.; Gillatt, D.; Harper, S.J. VEGF165b, an Inhibitory Splice Variant of Vascular Endothelial Growth Factor, Is Down-Regulated in Renal Cell Carcinoma. Cancer Res. 2003, 62, 10.

21. Lu, F.; Gladden, A.B.; Diehl, J.A. An Alternatively Spliced Cyclin D1 Isoform, Cyclin D1b, Is a Nuclear Oncogene 1. Cancer Res. 2020, 63, 7056-7061.

22. Naro, C.; Sette, C. Phosphorylation-Mediated Regulation of Alternative Splicing in Cancer. Int. J. Cell Biol. 2013, 2013, 151839. [CrossRef] [PubMed]

23. Shepard, P.J.; Hertel, K.J. The SR Protein Family. Genome Biol. 2009, 10, 242. [CrossRef] [PubMed]

24. Manley, J.L.; Tacke, R. SR Proteins and Splicing Control. Genes Dev. 1996, 10, 1569-1579. [CrossRef] [PubMed]

25. Cáceres, J.F.; Misteli, T.; Screaton, G.R.; Spector, D.L.; Krainer, A.R. Role of the Modular Domains of SR Proteins in Subnuclear Localization and Alternative Splicing Specificity. J. Cell Biol. 1997, 138, 225-238. [CrossRef]

26. Lai, M.-C.; Tarn, W.-Y. Hypophosphorylated ASF/SF2 Binds TAP and Is Present in Messenger Ribonucleoproteins. J. Biol. Chem. 2004, 279, 31745-31749. [CrossRef]

27. Zhou, Z.; Fu, X.-D. Regulation of Splicing by SR Proteins and SR Protein-Specific Kinases. Chromosoma 2013, 122, 191-207. [CrossRef]

28. Ding, S.; Shi, J.; Qian, W.; Iqbal, K.; Grundke-Iqbal, I.; Gong, C.-X.; Liu, F. Regulation of Alternative Splicing of Tau Exon 10 by 9 G8 and Dyrk1A. Neurobiol. Aging 2012, 33, 1389-1399. [CrossRef]

29. Smith, B.E.; Wang, S.L.; Jaime-Figueroa, S.; Harbin, A.; Wang, J.; Hamman, B.D.; Crews, C.M. Differential PROTAC Substrate Specificity Dictated by Orientation of Recruited E3 Ligase. Nat. Commun. 2019, 10, 131. [CrossRef] 
30. Shi, J.; Qian, W.; Yin, X.; Iqbal, K.; Grundke-Iqbal, I.; Gu, X.; Ding, F.; Gong, C.-X.; Liu, F. Cyclic AMP-Dependent Protein Kinase Regulates the Alternative Splicing of Tau Exon 10: A Mechanism Involved in Tau Pathology of Alzheimer Disease. J. Biol. Chem. 2011, 286, 14639-14648. [CrossRef]

31. Kvissel, A.-K.; Ørstavik, S.; Eikvar, S.; Brede, G.; Jahnsen, T.; Collas, P.; Akusjärvi, G.; Skålhegg, B.S. Involvement of the Catalytic Subunit of Protein Kinase A and of HA95 in Pre-MRNA Splicing. Exp. Cell Res. 2007, 313, 2795-2809. [CrossRef] [PubMed]

32. Simarro, M.; Mauger, D.; Rhee, K.; Pujana, M.A.; Kedersha, N.L.; Yamasaki, S.; Cusick, M.E.; Vidal, M.; Garcia-Blanco, M.A.; Anderson, P. Fas-Activated Serine/Threonine Phosphoprotein (FAST) Is a Regulator of Alternative Splicing. Proc. Natl. Acad. Sci. USA 2007, 104, 11370-11375. [CrossRef] [PubMed]

33. Moore, M.J.; Wang, Q.; Kennedy, C.J.; Silver, P.A. An Alternative Splicing Network Links Cell-Cycle Control to Apoptosis. Cell 2010, 142, 625-636. [CrossRef]

34. Weg-Remers, S. Regulation of Alternative Pre-MRNA Splicing by the ERK MAP-Kinase Pathway. EMBO J. 2001, 20, 4194-4203. [CrossRef] [PubMed]

35. Manning, G.; Whyte, D.B.; Martinez, R.; Hunter, T.; Sudarsanam, S. The Protein Kinase Complement of the Human Genome. Science 2002, 298, 1912-1934. [CrossRef] [PubMed]

36. Ben-David, Y.; Letwin, K.; Tannock, L.; Bernstein, A.; Pawson, T. A Mammalian Protein Kinase with Potential for Serine/Threonine and Tyrosine Phosphorylation Is Related to Cell Cycle Regulators. EMBO J. 1991, 10, 317-325. [CrossRef]

37. Howell, B.W.; Afar, D.E.; Lew, J.; Douville, E.M.; Icely, P.L.; Gray, D.A.; Bell, J.C. STY, a Tyrosine-Phosphorylating Enzyme with Sequence Homology to Serine/Threonine Kinases. Mol. Cell. Biol. 1991, 11, 568-572. [CrossRef]

38. UniProt Consortium. UniProt. Available online: https://www.uniprot.org/ (accessed on 19 March 2020).

39. Bullock, A.N.; Das, S.; Debreczeni, J.É.; Rellos, P.; Fedorov, O.; Niesen, F.H.; Guo, K.; Papagrigoriou, E.; Amos, A.L.; Cho, S.; et al. Kinase Domain Insertions Define Distinct Roles of CLK Kinases in SR Protein Phosphorylation. Structure 2009, 17, 352-362. [CrossRef]

40. Keri, G.; Orfi, L.; Eros, D.; Hegymegi-Barakonyi, B.; Szantai-Kis, C.; Horvath, Z.; Waczek, F.; Marosfalvi, J.; Szabadkai, I.; Pato, J.; et al. Signal Transduction Therapy with Rationally Designed Kinase Inhibitors. Curr. Signal Transduct. Ther. 2006, 1, 67-95. [CrossRef]

41. Knighton, D.; Zheng, J.; Ten Eyck, L.; Ashford, V.; Xuong, N.; Taylor, S.; Sowadski, J. Crystal Structure of the Catalytic Subunit of Cyclic Adenosine Monophosphate-Dependent Protein Kinase. Science 1991, 253, 407-414. [CrossRef]

42. Grant, S.K. Therapeutic Protein Kinase Inhibitors. Cell. Mol. Life Sci. 2009, 66, 1163-1177. [CrossRef] [PubMed]

43. Chaikuad, A. RCSB PDB-3NR9: Structure of Human CDC2-Like Kinase 2 (CLK2). Available online: https://www.rcsb.org/structure/3NR9 (accessed on 28 August 2020).

44. Zheng, G. RCSB PDB-1ATP: 2.2 Angstrom Refined Crystal Structure of the Catalytic Subunit of cAMP-Dependent Protein Kinase Complexed with MNATP and a Peptide Inhibitor. Available online: https://www.rcsb.org/structure/1ATP (accessed on 28 August 2020).

45. Lee, J.Y.; Yun, J.-S.; Kim, W.-K.; Chun, H.-S.; Jin, H.; Cho, S.; Chang, J.H. Structural Basis for the Selective Inhibition of Cdc2-Like Kinases by CX-4945. BioMed Res. Int. 2019, 2019, 6125068. [CrossRef] [PubMed]

46. Schröder, M.; Bullock, A.N.; Fedorov, O.; Bracher, F.; Chaikuad, A.; Knapp, S. DFG-1 Residue Controls Inhibitor Binding Mode and Affinity Providing a Basis for Rational Design of Kinase Inhibitor Selectivity. J. Med. Chem. 2020, 0c00898. [CrossRef] [PubMed]

47. Němec, V.; Hylsová, M.; Maier, L.; Flegel, J.; Sievers, S.; Ziegler, S.; Schröder, M.; Berger, B.; Chaikuad, A.; Valčíková, B.; et al. Furo[3,2-b]Pyridine: A Privileged Scaffold for Highly Selective Kinase Inhibitors and Effective Modulators of the Hedgehog Pathway. Angew. Chem. Int. Ed. 2019, 58, 1062-1066. [CrossRef]

48. Bank, R.P.D. RCSB PDB-6YTW: CLK3 Bound with Benzothiazole Tg003 (Cpd 2). Available online: https://www.rcsb.org/structure/6YTW (accessed on 2 October 2020).

49. Aubol, B.E.; Plocinik, R.M.; Hagopian, J.C.; Ma, C.-T.; McGlone, M.L.; Bandyopadhyay, R.; Fu, X.-D.; Adams, J.A. Partitioning RS Domain Phosphorylation in an SR Protein through the CLK and SRPK Protein Kinases. J. Mol. Biol. 2013, 425, 2894-2909. [CrossRef]

50. Ghosh, G.; Adams, J.A. Phosphorylation Mechanism and Structure of Serine-Arginine Protein Kinases: SRPK Structure and Mechanism. FEBS J. 2011, 278, 587-597. [CrossRef] 
51. Papagrigoriou, E. RCSB PDB-2EU9: Crystal Structure of CLK3. Available online: https://www.rcsb.org/ structure/2EU9 (accessed on 28 August 2020).

52. Prasad, J.; Manley, J.L. Regulation and Substrate Specificity of the SR Protein Kinase Clk/Sty. Mol. Cell. Biol. 2003, 23, 4139-4149. [CrossRef]

53. Nayler, O.; Stamm, S.; Ullrich, A. Characterization and Comparison of Four Serine- and Arginine-Rich (SR) Protein Kinases. Biochem. J. 1997, 326, 693-700. [CrossRef]

54. Colwill, K.; Pawson, T.; Andrews, B.; Prasad, J.; Manley, J.L.; Bell, J.C.; Duncan, P.I. The Clk/Sty Protein Kinase Phosphorylates SR Splicing Factors and Regulates Their Intranuclear Distribution. EMBO J. 1996, 15, 265-275. [CrossRef]

55. Aubol, B.E.; Wu, G.; Keshwani, M.M.; Movassat, M.; Fattet, L.; Hertel, K.J.; Fu, X.-D.; Adams, J.A. Release of SR Proteins from CLK1 by SRPK1: A Symbiotic Kinase System for Phosphorylation Control of Pre-MRNA Splicing. Mol. Cell 2016, 63, 218-228. [CrossRef]

56. Hochberg-Laufer, H.; Neufeld, N.; Brody, Y.; Nadav-Eliyahu, S.; Ben-Yishay, R.; Shav-Tal, Y. Availability of Splicing Factors in the Nucleoplasm Can Regulate the Release of MRNA from the Gene after Transcription. PLOS Genet. 2019, 15, e1008459. [CrossRef] [PubMed]

57. Shin, C.; Manley, J.L. The SR Protein SRp38 Represses Splicing in M Phase Cells. Cell 2002, 111, $407-417$. [CrossRef]

58. Shin, C.; Feng, Y.; Manley, J.L. Dephosphorylated SRp38 Acts as a Splicing Repressor in Response to Heat Shock. Nature 2004, 427, 553-558. [CrossRef] [PubMed]

59. Mermoud, J.E.; Cohen, P.; Lamond, A.I. Ser/Thr-Specific Protein Phosphatases Are Required for Both Catalytic Steps of Pre-MRNA Splicing. Nucleic Acids Res. 1992, 20, 5263-5269. [CrossRef]

60. Mermoud, J.E.; Cohen, P.T.; Lamond, A.I. Regulation of Mammalian Spliceosome Assembly by a Protein Phosphorylation Mechanism. EMBO J. 1994, 13, 5679-5688. [CrossRef]

61. Stojdl, D.F.; Bell, J.C. SR Protein Kinases: The Splice of Life. Biochem. Cell Biol. 1999, 77, 6. [CrossRef]

62. Huang, Y.; Gattoni, R.; Stévenin, J.; Steitz, J.A. SR Splicing Factors Serve as Adapter Proteins for TAP-Dependent MRNA Export. Mol. Cell 2003, 11, 837-843. [CrossRef]

63. Graveley, B.R. Sorting out the Complexity of SR Protein Functions. RNA 2000, 6, 1197-1211. [CrossRef]

64. Muraki, M.; Ohkawara, B.; Hosoya, T.; Onogi, H.; Koizumi, J.; Koizumi, T.; Sumi, K.; Yomoda, J.; Murray, M.V.; Kimura, H.; et al. Manipulation of Alternative Splicing by a Newly Developed Inhibitor of Clks. J. Biol. Chem. 2004, 279, 24246-24254. [CrossRef]

65. Johnson, K.; Smith, K. Molecular Cloning of a NovelHuman CdcZ/CDC28-like Protein Kinase. J. Biol. Chem. 1991, 25, 3402-3407.

66. Lew, J.; Qi, Z.; Huang, Q.-Q.; Paudel, H.; Matsuura, I.; Matsushita, M.; Zhu, X.; Wang, J.H. Structure, Function, and Regulation of Neuronal Cdc2-like Protein Kinase. Neurobiol. Aging 1995, 16, 263-268. [CrossRef]

67. Hanes, J.; von der Kammer, H.; Klaudiny, J.; Scheit, K.H. Characterization by CDNA Cloning of Two New Human Protein Kinases. J. Mol. Biol. 1994, 244, 665-672. [CrossRef] [PubMed]

68. George, A.; Aubol, B.E.; Fattet, L.; Adams, J.A. Disordered Protein Interactions for an Ordered Cellular Transition: Cdc2-like Kinase 1 Is Transported to the Nucleus via Its Ser-Arg Protein Substrate. J. Biol. Chem. 2019, 294, 9631-9641. [CrossRef] [PubMed]

69. Duncan, P.I.; Howell, B.W.; Marius, R.M.; Drmanic, S.; Douville, E.M.J.; Bell, J.C. Alternative Splicing of STY, a Nuclear Dual Specificity Kinase. J. Biol. Chem. 1995, 270, 21524-21531. [CrossRef]

70. Duncan, P.I.; Stojdl, D.F.; Marius, R.M.; Scheit, K.H.; Bell, J.C. The Clk2 and Clk3 Dual-Specificity Protein Kinases Regulate the Intranuclear Distribution of SR Proteins and Influence Pre-MRNA Splicing. Exp. Cell Res. 1998, 241, 300-308. [CrossRef]

71. Haltenhof, T.; Kotte, A.; De Bortoli, F.; Schiefer, S.; Meinke, S.; Emmerichs, A.-K.; Petermann, K.K.; Timmermann, B.; Imhof, P.; Franz, A.; et al. A Conserved Kinase-Based Body-Temperature Sensor Globally Controls Alternative Splicing and Gene Expression. Mol. Cell 2020, 78, 57-69.e4. [CrossRef]

72. Petsalaki, E.; Zachos, G. Clks 1, 2 and 4 Prevent Chromatin Breakage by Regulating the Aurora B-Dependent Abscission Checkpoint. Nat. Commun. 2016, 7, 11451. [CrossRef]

73. Lopez Soto, E.J.; Gandal, M.J.; Gonatopoulos-Pournatzis, T.; Heller, E.A.; Luo, D.; Zheng, S. Mechanisms of Neuronal Alternative Splicing and Strategies for Therapeutic Interventions. J. Neurosci. 2019, 39, 8193-8199. [CrossRef]

74. Wang, E.; Aifantis, I. RNA Splicing and Cancer. Trends Cancer 2020, 6, 631-644. [CrossRef] 
75. Ule, J.; Blencowe, B.J. Alternative Splicing Regulatory Networks: Functions, Mechanisms, and Evolution. Mol. Cell 2019, 76, 329-345. [CrossRef]

76. Tam, B.Y.; Chiu, K.; Chung, H.; Bossard, C.; Nguyen, J.D.; Creger, E.; Eastman, B.W.; Mak, C.C.; Ibanez, M.; Ghias, A.; et al. The CLK Inhibitor SM08502 Induces Anti-Tumor Activity and Reduces Wnt Pathway Gene Expression in Gastrointestinal Cancer Models. Cancer Lett. 2019, S0304383519304732. [CrossRef] [PubMed]

77. Glatz, D.C.; Rujescu, D.; Tang, Y.; Berendt, F.J.; Hartmann, A.M.; Faltraco, F.; Rosenberg, C.; Hulette, C.; Jellinger, K.; Hampel, H.; et al. The Alternative Splicing of Tau Exon 10 and Its Regulatory Proteins CLK2 and TRA2-BETA1 Changes in Sporadic Alzheimer's Disease. J. Neurochem. 2006, 96, 635-644. [CrossRef] [PubMed]

78. Hartmann, A.M.; Rujescu, D.; Giannakouros, T.; Nikolakaki, E.; Goedert, M.; Mandelkow, E.-M.; Gao, Q.S.; Andreadis, A.; Stamm, S. Regulation of Alternative Splicing of Human Tau Exon 10 by Phosphorylation of Splicing Factors. Mol. Cell. Neurosci. 2001, 18, 80-90. [CrossRef] [PubMed]

79. Barbier, P.; Zejneli, O.; Martinho, M.; Lasorsa, A.; Belle, V.; Smet-Nocca, C.; Tsvetkov, P.O.; Devred, F.; Landrieu, I. Role of Tau as a Microtubule-Associated Protein: Structural and Functional Aspects. Front. Aging Neurosci. 2019, 11, 204. [CrossRef] [PubMed]

80. Uzor, S.; Zorzou, P.; Bowler, E.; Porazinski, S.; Wilson, I.; Ladomery, M. Autoregulation of the Human Splice Factor Kinase CLK1 through Exon Skipping and Intron Retention. Gene 2018, 670, 46-54. [CrossRef] [PubMed]

81. Keshwani, M.M.; Hailey, K.L.; Aubol, B.E.; Fattet, L.; McGlone, M.L.; Jennings, P.A.; Adams, J.A. Nuclear Protein Kinase CLK1 Uses a Non-Traditional Docking Mechanism to Select Physiological Substrates. Biochem. J. 2015, 472, 329-338. [CrossRef]

82. Tang, Z.; Luca, M.; Portillio, J.; Ngo, B.; Chang, C.; Wen, T.; Murray, J.; Carr, A. LAMMER Kinase Kic1 Is Involved in Pre-MRNA Processing. Exp. Cell Res. 2011, 317, 2308-2320. [CrossRef]

83. Giannakouros, T.; Nikolakaki, E.; Mylonis, I.; Georgatsou, E. Serine-Arginine Protein Kinases: A Small Protein Kinase Family with a Large Cellular Presence: Serine-Arginine Protein Kinases. FEBS J. 2011, 278, 570-586. [CrossRef]

84. Aubol, B.E.; Keshwani, M.M.; Fattet, L.; Adams, J.A. Mobilization of a Splicing Factor through a Nuclear Kinase-Kinase Complex. Biochem. J. 2018, 475, 677-690. [CrossRef]

85. Aubol, B.E.; Fattet, L.; Adams, J.A. A Conserved Sequence Motif Bridges Two Protein Kinases for Enhanced Phosphorylation and Nuclear Function of a Splicing Factor. FEBS J. 2020, 15351. [CrossRef]

86. Aubol, B.E.; Plocinik, R.M.; Keshwani, M.M.; McGlone, M.L.; Hagopian, J.C.; Ghosh, G.; Fu, X.-D.; Adams, J.A. N-Terminus of the Protein Kinase CLK1 Induces SR Protein Hyperphosphorylation. Biochem. J. 2014, 462, 143-152. [CrossRef] [PubMed]

87. Liu, Y.; Conaway, L.; Rutherford Bethard, J.; Al-Ayoubi, A.M.; Thompson Bradley, A.; Zheng, H.; Weed, S.A.; Eblen, S.T. Phosphorylation of the Alternative MRNA Splicing Factor 45 (SPF45) by Clk1 Regulates Its Splice Site Utilization, Cell Migration and Invasion. Nucleic Acids Res. 2013, 41, 4949-4962. [CrossRef] [PubMed]

88. Jiang, K.; Patel, N.A.; Watson, J.E.; Apostolatos, H.; Kleiman, E.; Hanson, O.; Hagiwara, M.; Cooper, D.R. Akt2 Regulation of Cdc2-Like Kinases (Clk/Sty), Serine/Arginine-Rich (SR) Protein Phosphorylation, and Insulin-Induced Alternative Splicing of PKC $\beta$ II Messenger Ribonucleic Acid. Endocrinology 2009, 150, 2087-2097. [CrossRef] [PubMed]

89. Saldivia, M.; Rao, S.P.S.; Fang, E.; Myburgh, E.; Brown, E.; Wollman, A.J.M.; Ritchie, R.; Lakhsminarayana, S.B.; Chen, Y.L.; Patra, D.; et al. Targeting the Trypanosome Kinetochore with CLK1 Protein Kinase Inhibitors. Nat. Microbiol. 2019. preprint. [CrossRef]

90. Sun, Q.-Z.; Lin, G.-F.; Li, L.-L.; Jin, X.-T.; Huang, L.-Y.; Zhang, G.; Yang, W.; Chen, K.; Xiang, R.; Chen, C.; et al. Discovery of Potent and Selective Inhibitors of Cdc2-Like Kinase 1 (CLK1) as a New Class of Autophagy Inducers. J. Med. Chem. 2017, 60, 6337-6352. [CrossRef]

91. Fant, X.; Durieu, E.; Chicanne, G.; Payrastre, B.; Sbrissa, D.; Shisheva, A.; Limanton, E.; Carreaux, F.; Bazureau, J.-P.; Meijer, L. Cdc-Like/Dual-Specificity Tyrosine Phosphorylation-Regulated Kinases Inhibitor Leucettine L41 Induces MTOR-Dependent Autophagy: Implication for Alzheimer's Disease. Mol. Pharmacol. 2014, 85, 441-450. [CrossRef]

92. Tabata, M.; Rodgers, J.T.; Hall, J.A.; Lee, Y.; Jedrychowski, M.P.; Gygi, S.P.; Puigserver, P. Cdc2-Like Kinase 2 Suppresses Hepatic Fatty Acid Oxidation and Ketogenesis Through Disruption of the PGC-1 $\alpha$ and MED1 Complex. Diabetes 2014, 63, 1519-1532. [CrossRef] 
93. Hatting, M.; Rines, A.K.; Luo, C.; Tabata, M.; Sharabi, K.; Hall, J.A.; Verdeguer, F.; Trautwein, C.; Puigserver, P. Adipose Tissue CLK2 Promotes Energy Expenditure during High-Fat Diet Intermittent Fasting. Cell Metab. 2017, 25, 428-437. [CrossRef]

94. Nam, S.Y.; Seo, H.H.; Park, H.S.; An, S.; Kim, J.-Y.; Yang, K.H.; Kim, C.S.; Jeong, M.; Jin, Y.-W. Phosphorylation of CLK2 at Serine 34 and Threonine 127 by AKT Controls Cell Survival after Ionizing Radiation. J. Biol. Chem. 2010, 285, 31157-31163. [CrossRef]

95. Moeslein, F.M.; Myers, M.P.; Landreth, G.E. The CLK Family Kinases, CLK1 and CLK2, Phosphorylate and Activate the Tyrosine Phosphatase, PTP-1B. J. Biol. Chem. 1999, 274, 26697-26704. [CrossRef]

96. Kulkarni, P.; Jolly, M.K.; Jia, D.; Mooney, S.M.; Bhargava, A.; Kagohara, L.T.; Chen, Y.; Hao, P.; He, Y.; Veltri, R.W.; et al. Phosphorylation-Induced Conformational Dynamics in an Intrinsically Disordered Protein and Potential Role in Phenotypic Heterogeneity. Proc. Natl. Acad. Sci. USA 2017, 114, E2644-E2653. [CrossRef] [PubMed]

97. Menegay, H.; Moeslein, F.; Landreth, G. The Dual Specificity Protein Kinase CLK3 Is Abundantly Expressed in Mature Mouse Spermatozoa. Exp. Cell Res. 1999, 253, 463-473. [CrossRef] [PubMed]

98. Ninomiya, K.; Adachi, S.; Natsume, T.; Iwakiri, J.; Terai, G.; Asai, K.; Hirose, T. Lnc RNA -dependent Nuclear Stress Bodies Promote Intron Retention through SR Protein Phosphorylation. EMBO J. 2020, 39. [CrossRef] [PubMed]

99. Gui, J.-F.; Lane, W.S.; Fu, X.-D. A Serine Kinase Regulates Intracellular Localization of Splicing Factors in the Cell Cycle. Nature 1994, 369, 678-682. [CrossRef]

100. Dostie, J.; Lejbkowicz, F.; Sonenberg, N. Nuclear Eukaryotic Initiation Factor 4e (Eif4e) Colocalizes with Splicing Factors in Speckles. J. Cell Biol. 2000, 148, 239-246. [CrossRef]

101. Sacco-Bubulya, P.; Spector, D.L. Disassembly of Interchromatin Granule Clusters Alters the Coordination of Transcription and Pre-MRNA Splicing. J. Cell Biol. 2002, 156, 425-436. [CrossRef]

102. Lai, M.-C.; Lin, R.-I.; Tarn, W.-Y. Differential Effects of Hyperphosphorylation on Splicing Factor SRp55. Biochem. J. 2003, 371, 937-945. [CrossRef]

103. Duncan, P.I.; Stojdl, D.F.; Marius, R.M.; Bell, J.C. In Vivo Regulation of Alternative Pre-MRNA Splicing by the Clk1 Protein Kinase. Mol. Cell. Biol. 1997, 17, 5996-6001. [CrossRef]

104. Rieder, D.; Ploner, C.; Krogsdam, A.M.; Stocker, G.; Fischer, M.; Scheideler, M.; Dani, C.; Amri, E.-Z.; Müller, W.G.; McNally, J.G.; et al. Co-Expressed Genes Prepositioned in Spatial Neighborhoods Stochastically Associate with SC35 Speckles and RNA Polymerase II Factories. Cell. Mol. Life Sci. 2014, 71, 1741-1759. [CrossRef]

105. García-Sacristán, A.; Fernández-Nestosa, M.J.; Hernández, P.; Schvartzman, J.B.; Krimer, D.B. Protein Kinase Clk/STY Is Differentially Regulated during Erythroleukemia Cell Differentiation: A Bias toward the Skipped Splice Variant Characterizes Postcommitment Stages. Cell Res. 2005, 15, 495-503. [CrossRef]

106. Alfonso, J.; Frick, L.R.; Silberman, D.M.; Palumbo, M.L.; Genaro, A.M.; Frasch, A.C. Regulation of Hippocampal Gene Expression Is Conserved in Two Species Subjected to Different Stressors and Antidepressant Treatments. Biol. Psychiatry 2006, 59, 244-251. [CrossRef] [PubMed]

107. Virgirinia, R.P.; Jahan, N.; Okada, M.; Takebayashi-Suzuki, K.; Yoshida, H.; Nakamura, M.; Akao, H.; Yoshimoto, Y.; Fatchiyah, F.; Ueno, N.; et al. Cdc2-like Kinase 2 (Clk2) Promotes Early Neural Development in Xenopus Embryos. Dev. Growth Differ. 2019, 61, 365-377. [CrossRef] [PubMed]

108. Yoshida, T.; Kim, J.H.; Carver, K.; Su, Y.; Weremowicz, S.; Mulvey, L.; Yamamoto, S.; Brennan, C.; Mei, S.; Long, H.; et al. CLK2 Is an Oncogenic Kinase and Splicing Regulator in Breast Cancer. Cancer Res. 2015, 75, 1516-1526. [CrossRef] [PubMed]

109. Li, H.; Cui, X.; Hu, Q.; Chen, X.; Zhou, P. CLK3 Is A Direct Target of MiR-144 and Contributes To Aggressive Progression in Hepatocellular Carcinoma. OncoTargets Ther. 2019, 12, 9201-9213. [CrossRef] [PubMed]

110. Quaresma, P.G.F.; Weissmann, L.; Zanotto, T.M.; Santos, A.C.; de Matos, A.H.B.; Furigo, I.C.; Simabuco, F.M.; Donato, J., Jr.; Bittencourt, J.C.; Lopes-Cendes, I.; et al. Cdc2-like Kinase 2 in the Hypothalamus Is Necessary to Maintain Energy Homeostasis. Int. J. Obes. 2017, 41, 268-278. [CrossRef] [PubMed]

111. Rodgers, J.T.; Haas, W.; Gygi, S.P.; Puigserver, P. Cdc2-like Kinase 2 Is an Insulin-Regulated Suppressor of Hepatic Gluconeogenesis. Cell Metab. 2010, 11, 23-34. [CrossRef] [PubMed]

112. Srebrow, A. The Connection between Splicing and Cancer. J. Cell Sci. 2006, 119, 2635-2641. [CrossRef]

113. Escobar-Hoyos, L.; Knorr, K.; Abdel-Wahab, O. Aberrant RNA Splicing in Cancer. Annu. Rev. Cancer Biol. 2019, 3, 167-185. [CrossRef] 
114. El Marabti, E.; Younis, I. The Cancer Spliceome: Reprograming of Alternative Splicing in Cancer. Front. Mol. Biosci. 2018, 5, 80. [CrossRef]

115. Graubert, T.A.; Shen, D.; Ding, L.; Okeyo-Owuor, T.; Lunn, C.L.; Shao, J.; Krysiak, K.; Harris, C.C.; Koboldt, D.C.; Larson, D.E.; et al. Recurrent Mutations in the U2AF1 Splicing Factor in Myelodysplastic Syndromes. Nat. Genet. 2012, 44, 53-57. [CrossRef]

116. Bonnal, S.C.; López-Oreja, I.; Valcárcel, J. Roles and Mechanisms of Alternative Splicing in Cancer-Implications for Care. Nat. Rev. Clin. Oncol. 2020, 17, 457-474. [CrossRef] [PubMed]

117. Dvinge, H.; Kim, E.; Abdel-Wahab, O.; Bradley, R.K. RNA Splicing Factors as Oncoproteins and Tumour Suppressors. Nat. Rev. Cancer 2016, 16, 413-430. [CrossRef] [PubMed]

118. Iwai, K.; Yaguchi, M.; Nishimura, K.; Yamamoto, Y.; Tamura, T.; Nakata, D.; Dairiki, R.; Kawakita, Y.; Mizojiri, R.; Ito, Y.; et al. Anti-tumor Efficacy of a Novel CLK Inhibitor via Targeting RNA Splicing and MYC-dependent Vulnerability. EMBO Mol. Med. 2018, 10. [CrossRef] [PubMed]

119. Di Maira, G.; Gentilini, A.; Pastore, M.; Caligiuri, A.; Piombanti, B.; Raggi, C.; Rovida, E.; Lewinska, M.; Andersen, J.B.; Borgo, C.; et al. The Protein Kinase CK2 Contributes to the Malignant Phenotype of Cholangiocarcinoma Cells. Oncogenesis 2019, 8, 61. [CrossRef]

120. Intervention Dynamic Trial Listing Page. Available online: https://www.cancer.gov/about-cancer/treatment/ clinical-trials/intervention/silmitasertib-sodium (accessed on 28 August 2020).

121. Park, S.Y.; Piao, Y.; Thomas, C.; Fuller, G.N.; de Groot, J.F. Cdc2-like Kinase 2 Is a Key Regulator of the Cell Cycle via FOXO3a/P27 in Glioblastoma. Oncotarget 2016, 7, 26793-26805. [CrossRef]

122. Wong, R.; Balachandran, A.; Mao, A.Y.; Dobson, W.; Gray-Owen, S.; Cochrane, A. Differential Effect of CLK SR Kinases on HIV-1 Gene Expression: Potential Novel Targets for Therapy. Retrovirology 2011, 8, 47. [CrossRef]

123. Lee, K.-Y.; Clark, A.W.; Rosales, J.L.; Chapman, K.; Fung, T.; Johnston, R.N. Elevated Neuronal Cdc2-like Kinase Activity in the Alzheimer Disease Brain. Neurosci. Res. 1999, 34, 21-29. [CrossRef]

124. Irwin, D.J. Tauopathies as Clinicopathological Entities. Parkinsonism Relat. Disord. 2016, 22, S29-S33. [CrossRef]

125. Ledesma, M.D.; Correas, I.; Avila, J.; Diaz-Nido, J. Implication of Brain Cdc2 and MAP2 Kinases in the Phosphorylation of Tau Protein in Alzheimer's Disease. FEBS Lett. 1992, 308, 218-224. [CrossRef]

126. Jain, P.; Karthikeyan, C.; Moorthy, N.S.; Waiker, D.; Jain, A.; Trivedi, P. Human CDC2-Like Kinase 1 (CLK1): A Novel Target for Alzheimer's Disease. Curr. Drug Targets 2014, 15, 539-550. [CrossRef]

127. Sako, Y.; Ninomiya, K.; Okuno, Y.; Toyomoto, M.; Nishida, A.; Koike, Y.; Ohe, K.; Kii, I.; Yoshida, S.; Hashimoto, N.; et al. Development of an Orally Available Inhibitor of CLK1 for Skipping a Mutated Dystrophin Exon in Duchenne Muscular Dystrophy. Sci. Rep. 2017, 7, 46126. [CrossRef] [PubMed]

128. Artarini, A.; Meyer, M.; Shin, Y.J.; Huber, K.; Hilz, N.; Bracher, F.; Eros, D.; Orfi, L.; Keri, G.; Goedert, S.; et al. Regulation of Influenza A Virus MRNA Splicing by CLK1. Antivir. Res. 2019, 168, 187-196. [CrossRef] [PubMed]

129. Bidinosti, M.; Botta, P.; Krüttner, S.; Proenca, C.C.; Stoehr, N.; Bernhard, M.; Fruh, I.; Mueller, M.; Bonenfant, D.; Voshol, H.; et al. CLK2 Inhibition Ameliorates Autistic Features Associated with SHANK3 Deficiency. Science 2016, 351, 1199-1203. [CrossRef] [PubMed]

130. Alam, M.M.; Sanchez-Azqueta, A.; Janha, O.; Flannery, E.L.; Mahindra, A.; Mapesa, K.; Char, A.B.; Sriranganadane, D.; Brancucci, N.M.B.; Antonova-Koch, Y.; et al. Validation of the Protein Kinase Pf CLK3 as a Multistage Cross-Species Malarial Drug Target. Science 2019, 365, 1682. [CrossRef] [PubMed]

131. Mahindra, A.; Janha, O.; Mapesa, K.; Sanchez-Azqueta, A.; Alam, M.M.; Amambua-Ngwa, A.; Nwakanma, D.C.; Tobin, A.B.; Jamieson, A.G. Development of Potent Pf CLK3 Inhibitors Based on TCMDC-135051 as a New Class of Antimalarials. J. Med. Chem. 2020, 63, 9300-9315. [CrossRef]

132. Kubori, T.; Hyakutake, A.; Nagai, H. Legionella Translocates an E3 Ubiquitin Ligase That Has Multiple U-Boxes with Distinct Functions. Mol. Microbiol. 2008, 67, 1307-1319. [CrossRef] [PubMed]

133. Kallen, J.; Bergsdorf, C.; Arnaud, B.; Bernhard, M.; Brichet, M.; Cobos-Correa, A.; Elhajouji, A.; Freuler, F.; Galimberti, I.; Guibourdenche, C.; et al. X-ray Structures and Feasibility Assessment of CLK2 Inhibitors for Phelan-McDermid Syndrome. ChemMedChem 2018, 13, 1997-2007. [CrossRef]

134. Mott, B.T.; Tanega, C.; Shen, M.; Maloney, D.J.; Shinn, P.; Leister, W.; Marugan, J.J.; Inglese, J.; Austin, C.P.; Misteli, T.; et al. Evaluation of Substituted 6-Arylquinazolin-4-Amines as Potent and Selective Inhibitors of Cdc2-like Kinases (Clk). Bioorg. Med. Chem. Lett. 2009, 19, 6700-6705. [CrossRef] 
135. Funnell, T.; Tasaki, S.; Oloumi, A.; Araki, S.; Kong, E.; Yap, D.; Nakayama, Y.; Hughes, C.S.; Cheng, S.-W.G.; Tozaki, H.; et al. CLK-Dependent Exon Recognition and Conjoined Gene Formation Revealed with a Novel Small Molecule Inhibitor. Nat. Commun. 2017, 8, 7. [CrossRef]

136. Mallinger, A.; Schiemann, K.; Rink, C.; Stieber, F.; Calderini, M.; Crumpler, S.; Stubbs, M.; Adeniji-Popoola, O.; Poeschke, O.; Busch, M.; et al. Discovery of Potent, Selective, and Orally Bioavailable Small-Molecule Modulators of the Mediator Complex-Associated Kinases CDK8 and CDK19. J. Med. Chem. 2016, 59, 1078-1101. [CrossRef]

137. Zhu, D.; Xu, S.; Deyanat-Yazdi, G.; Peng, S.X.; Barnes, L.A.; Narla, R.K.; Tran, T.; Mikolon, D.; Ning, Y.; Shi, T.; et al. Synthetic Lethal Strategy Identifies a Potent and Selective TTK and CLK1/2 Inhibitor for Treatment of Triple-Negative Breast Cancer with a Compromised $G_{1}-S$ Checkpoint. Mol. Cancer Ther. 2018, 17, 1727-1738. [CrossRef] [PubMed]

138. Rosenthal, A.; Tanega, C.; Shen, M.; Mott, B.; Bougie, J.; Nguyen, D.-T.; Misteli, T.; Auld, D.; Maloney, D.; Thomas, C. An Inhibitor of the Cdc2-like Kinase 4 (Clk4). In Probe Reports from the NIH Molecular Libraries Program [Internet]; National Center for Biotechnology Information: Bethesda, MD, USA, 2010.

139. Kim, H.; Choi, K.; Kang, H.; Lee, S.-Y.; Chi, S.-W.; Lee, M.-S.; Song, J.; Im, D.; Choi, Y.; Cho, S. Identification of a Novel Function of CX-4945 as a Splicing Regulator. PLoS ONE 2014, 9, e94978. [CrossRef] [PubMed]

140. Battistutta, R.; Cozza, G.; Pierre, F.; Papinutto, E.; Lolli, G.; Sarno, S.; O’Brien, S.E.; Siddiqui-Jain, A.; Haddach, M.; Anderes, K.; et al. Unprecedented Selectivity and Structural Determinants of a New Class of Protein Kinase CK2 Inhibitors in Clinical Trials for the Treatment of Cancer. Biochemistry 2011, 50, 8478-8488. [CrossRef] [PubMed]

141. Fedorov, O.; Huber, K.; Eisenreich, A.; Filippakopoulos, P.; King, O.; Bullock, A.N.; Szklarczyk, D.; Jensen, L.J.; Fabbro, D.; Trappe, J.; et al. Specific CLK Inhibitors from a Novel Chemotype for Regulation of Alternative Splicing. Chem. Biol. 2011, 18, 67-76. [CrossRef] [PubMed]

142. Tahtouh, T.; Elkins, J.M.; Filippakopoulos, P.; Soundararajan, M.; Burgy, G.; Durieu, E.; Cochet, C.; Schmid, R.S.; Lo, D.C.; Delhommel, F.; et al. Selectivity, Cocrystal Structures, and Neuroprotective Properties of Leucettines, a Family of Protein Kinase Inhibitors Derived from the Marine Sponge Alkaloid Leucettamine B. J. Med. Chem. 2012, 55, 9312-9330. [CrossRef]

143. Coombs, T.C.; Tanega, C.; Shen, M.; Wang, J.L.; Auld, D.S.; Gerritz, S.W.; Schoenen, F.J.; Thomas, C.J.; Aubé, J. Small-Molecule Pyrimidine Inhibitors of the Cdc2-like (Clk) and Dual Specificity Tyrosine Phosphorylation-Regulated (Dyrk) Kinases: Development of Chemical Probe ML315. Bioorg. Med. Chem. Lett. 2013, 23, 3654-3661. [CrossRef]

144. Schmitt, C.; Kail, D.; Mariano, M.; Empting, M.; Weber, N.; Paul, T.; Hartmann, R.W.; Engel, M. Design and Synthesis of a Library of Lead-Like 2,4-Bisheterocyclic Substituted Thiophenes as Selective Dyrk/Clk Inhibitors. PLoS ONE 2014, 9, e87851. [CrossRef]

145. Prak, K.; Kriston-Vizi, J.; Chan, A.W.E.; Luft, C.; Costa, J.R.; Pengo, N.; Ketteler, R. Benzobisthiazoles Represent a Novel Scaffold for Kinase Inhibitors of CLK Family Members. Biochemistry 2016, 55, 608-617. [CrossRef]

146. Araki, S.; Dairiki, R.; Nakayama, Y.; Murai, A.; Miyashita, R.; Iwatani, M.; Nomura, T.; Nakanishi, O. Inhibitors of CLK Protein Kinases Suppress Cell Growth and Induce Apoptosis by Modulating Pre-MRNA Splicing. PLoS ONE 2015, 10, e0116929. [CrossRef]

147. Shi, Y.; Park, J.; Lagisetti, C.; Zhou, W.; Sambucetti, L.C.; Webb, T.R. A Triple Exon-Skipping Luciferase Reporter Assay Identifies a New CLK Inhibitor Pharmacophore. Bioorg. Med. Chem. Lett. 2017, 27, 406-412. [CrossRef]

148. T3-CLK. A Chemical Probe for CLK Kinases. SGC Chem. Probes. Available online: https://www.thesgc.org/ chemical-probes/T3-CLK (accessed on 12 October 2020).

149. Walter, A.; Chaikuad, A.; Helmer, R.; Loaëc, N.; Preu, L.; Ott, I.; Knapp, S.; Meijer, L.; Kunick, C. Molecular Structures of Cdc2-like Kinases in Complex with a New Inhibitor Chemotype. PLoS ONE 2018, 13, e0196761. [CrossRef] [PubMed]

150. Tazarki, H.; Zeinyeh, W.; Esvan, Y.J.; Knapp, S.; Chatterjee, D.; Schröder, M.; Joerger, A.C.; Khiari, J.; Josselin, B.; Baratte, B.; et al. New Pyrido[3,4-g]Quinazoline Derivatives as CLK1 and DYRK1A Inhibitors: Synthesis, Biological Evaluation and Binding Mode Analysis. Eur. J. Med. Chem. 2019, 166, 304-317. [CrossRef] [PubMed] 
151. SGC-CLK-1. A Chemical Probe for CLK1, CLK2, and CLK4. SGC Chem. Probes. Available online: https://www.thesgc.org/chemical-probes/SGC-CLK-1 (accessed on 12 October 2020).

152. MU1210. A Chemical Probe for CLK Kinases. SGC Chem. Probes. Available online: https://www.thesgc.org/ chemical-probes/MU1210 (accessed on 12 October 2020).

153. Rosenthal, A.S.; Tanega, C.; Shen, M.; Mott, B.T.; Bougie, J.M.; Nguyen, D.-T.; Misteli, T.; Auld, D.S.; Maloney, D.J.; Thomas, C.J. Potent and Selective Small Molecule Inhibitors of Specific Isoforms of Cdc2-like Kinases (Clk) and Dual Specificity Tyrosine-Phosphorylation-Regulated Kinases (Dyrk). Bioorg. Med. Chem. Lett. 2011, 21, 3152-3158. [CrossRef] [PubMed]

154. Frye, S.V. The Art of the Chemical Probe. Nat. Chem. Biol. 2010, 6, 159-161. [CrossRef]

155. Workman, P.; Collins, I. Probing the Probes: Fitness Factors for Small Molecule Tools. Chem. Biol. 2010, 17, 561-577. [CrossRef]

156. Knapp, S.; Arruda, P.; Blagg, J.; Burley, S.; Drewry, D.H.; Edwards, A.; Fabbro, D.; Gillespie, P.; Gray, N.S.; Kuster, B.; et al. A Public-Private Partnership to Unlock the Untargeted Kinome. Nat. Chem. Biol. 2013, 9 , 3-6. [CrossRef]

(C) 2020 by the authors. Licensee MDPI, Basel, Switzerland. This article is an open access article distributed under the terms and conditions of the Creative Commons Attribution (CC BY) license (http://creativecommons.org/licenses/by/4.0/). 